\title{
Seasonal variability in bio-optical properties along the coastal waters off Cochin
}

\author{
P.S. Vishnu ${ }^{\mathrm{a}, *}$, S.S. Shaju ${ }^{\mathrm{b}}$, S.P. Tiwari ${ }^{\mathrm{c}}$, Nandini Menon ${ }^{\mathrm{d}}$, M. Nashad ${ }^{\mathrm{e}}$, C. Ajith Joseph ${ }^{\mathrm{a}}$, Mini Raman ${ }^{\mathrm{f}}$, \\ Mohamed Hatha ${ }^{\mathrm{a}}$, M.P. Prabhakaran' ${ }^{\mathrm{g}}$, A. Mohandas ${ }^{\mathrm{h}}$ \\ a Department of Marine Biology, Microbiology and Biochemistry, School of Marine Sciences, Cochin University of Science and Technology (CUSAT), Cochin, 682016, India \\ ${ }^{\mathrm{b}}$ Naval Physical Oceanographic Laboratory (NPOL), NGO Quarters, Thrikkakara, Cochin, Kerala, 682021, India \\ ${ }^{c}$ King Abdullah University of Science and Technology (KAUST), Red Sea Research Center (RSRC), Biological and Environmental Sciences \& Engineering Division (BESE), Thuwal, 23955-6900, \\ Saudi Arabia \\ ${ }^{\mathrm{d}}$ Nansen Environmental Research Centre (India) (NERCI), 6A Oxford Business Centre, Cochin, 682016, India \\ e Fishery Survey of India, Port Blair Base, Phoenix Bay Jetty, PB-744101, Andaman and Nicobar Islands, India \\ ${ }^{\mathrm{f}}$ Space Application Centre(SAC), Indian Space Research Organization (ISRO), Ahmedabad, 300015, India \\ ${ }^{g}$ Department of Fishery Hydrography, School of FRM\&HT, KUFOS, Cochin, 682056, Kerala, India \\ ${ }^{\mathrm{h}}$ National Centre for Aquatic Animal Health, PB No. 2341, Cochin University of Science and Technology Cochin, 682 016, Kerala, India
}

\section{A R T I C L E I N F O}

\section{Keywords:}

Southwest monsoon

Bio-optical properties

Pigment packaging

Phytoplankton

Coastal waters off Cochin

\begin{abstract}
A B S T R A C T
Strong seasonal upwelling, downwelling, changes in current patterns and the volume of freshwater discharge from Cochin Estuary defines the coastal waters off Cochin. These coastal waters were investigated through monthly sampling efforts during March 2015 to February 2016 to study the seasonal and spatial variability in bio-optical properties for the four different seasons mainly Spring Inter Monsoon (SIM), South West Monsoon (SWM), Fall Inter Monsoon (FIM) and Winter Monsoon (WM). The Barmouth region is the meeting place where freshwater from Cochin Estuary directly enters to the sea through a single narrow outlet, was dominated by highly turbid waters during the entire period of study. Among the four seasons, chlorophyll $a$ (Chl_a) concentration showed a high value during SWM, ranged from 2.90 to $11.66 \mathrm{mg} \mathrm{m}^{-3}$ with an average value of $6.56 \pm 3.51 \mathrm{mg} \mathrm{m}^{-3}$. During SIM the distribution of coloured dissolved organic matter (CDOM) is controlled by decomposition of phytoplankton biomass and the river discharge, whereas during SWM the temporal distribution of CDOM is controlled only by river discharge. The highest value for CDOM spectral slope $\left(\mathrm{S}_{\mathrm{CDOM}}\right)$ was observed during SWM, ranged from 0.013 to $0.020 \mathrm{~nm}^{-1}$ with an average value of $0.015 \pm 0.002 \mathrm{~nm}^{-1}$. During WM, the high $\mathrm{S}_{\mathrm{CDOM}}$ with lower $a_{\mathrm{CDOM}}(443)$ indicates the photo-degradation affects the absorption characteristics of CDOM. The observed nonlinearity between Chl_ $a$ and the ratio of phytoplankton absorption $a_{\mathrm{ph}}(443) / a_{\mathrm{ph}}(670)$ indicating the packaging effect and changes in the intercellular composition of pigments. During the study period, $a_{\mathrm{ph}}$ (670) was strongly correlated with Chl_ $a$ than $a_{\mathrm{ph}}$ (443), which explains the accessory pigment absorption dominating more than Chl_a in the blue part of the spectrum. Similarly, the results obtained from seasonal bio-optical data indicating that Chl_a significantly contributes light attenuation of the water column during SIM, whereas detritus $\left(a_{\mathrm{d}}\right)$ significantly contributes light attenuation during SIM and WM. During the study period, the relative absorption of detritus materials dominates the relative absorption of phytoplankton and CDOM at 443, 555 and $670 \mathrm{~nm}$ wavelengths.
\end{abstract}

\section{Introduction}

The coastal oceans are among the most dynamic environments, covering around $8 \%$ of the surface area of the globe, $15 \%$ of the global biological production, $80 \%$ of the global organic burial and around 75-
$90 \%$ of the global sink of suspended river load (Tilstone et al., 2012; Bauer et al., 2013; Loisel et al., 2013). However, these dynamic systems are now affected by harmful algal blooms, eutrophication and climate change (Shanmugam 2011; Davidson et al., 2014; Blondeau-patissier et al., 2014). Therefore, it is necessary to monitor the coastal oceans on a synoptic scale to observe the changes caused by the environment as well as human interventions (Mélin and Vantrepotte,

\footnotetext{
* Corresponding author.

Email address: vishnu@gmail.com, psvishnu2014@gmail.com (P.S. Vishnu)
} 
2015), which is possible through the remote estimation of ocean colour components. The retrieval of Inherent Optical Properties (IOPs - absorption and scattering) from remote sensing reflectance are well documented for the clear oceanic waters and a few for the coastal waters (Brewin et al., 2012; Bélanger et al., 2013; Zheng et al., 2014; Siegel et al., 2013; Knaeps et al., 2015; Dogliotti et al., 2015). Therefore, to improve the ocean colour estimates, it is essential to develop the robust regional algorithms for the coastal waters. An accurate estimation of ocean colour of bio-optical variables in the complex coastal waters is still a challenging task (Gokul et al., 2014). The bio-optical properties of the coastal water bodies are understudied (Tilstone et al., 2013; Ferreira et al., 2014) due to the optical complexity of the waters. Understanding the spatiotemporal variability of bio-optical properties in the coastal water bodies is essential to studies concerned with the upper ocean biogeochemical processes as well as the condition of the ecological environment. However, it required more efforts to characterize the bio-optical properties of coastal waters (Devred et al., 2013; Garaba et al., 2014; Mouw et al., 2015; Han et al., 2016). The coastal waters are influenced not only by phytoplankton and its byproducts, but also by other optically active substances (Moore et al., 2014; Barnes et al., 2014; Zhang et al., 2014a, 2014b; Sun et al., 2014) that vary independently of phytoplankton, like particles in suspension and CDOM (Blondeau-patissier et al., 2017; Menon et al., 2011; Tilstone et al., 2012; Brezonik et al., 2015; Pérez et al., 2016). CDOM is a part of the dissolved organic carbon (DOC) pool composed essentially fulvic and humic acid (Tiwari and Shanmugam, 2011; Organelli et al., 2014; Xing et al., 2014). It plays a significant role in underwater light attenuation and photochemically mediated biogeochemical processes in the clear and coastal waters (Nelson et al., 2010; Campanelli et al., 2017). The critical sources of CDOM in coastal waters are river discharge, upwelled bottom water and biological origins such as decomposition of phytoplankton, bacterial degradation, and photodegradation of other organic matter (Mannino et al., 2014). The spectral signature of detritus or non-algal particles can significantly alter the colour of coastal ocean (Zhang et al., 2014a,b). The retrieval of detritus substances is complicated due to the different types of organic and inorganic particles. (Zhang et al., 2014a,b; Riddick et al., 2015). Knowledge on the phytoplankton absorption $\left(a_{\mathrm{ph}}\right)$ spectra in seawater are necessary for modeling underwater light availability, primary productivity, and even for studying mixed layer dynamics (Zhai et al., 2011; Varunan and Shanmugam, 2015; Uitz et al., 2015). However, the penetration of light into the water column is necessary for understanding photosynthesis, optical bathymetry and photochemical process involved in the biogeochemical cycling of various elements.

Bio-optical studies reported along the coastal waters of South Eastern Arabian Sea (SEAS) are scarce due to lack of bio-optical measurements. The optically active constituent of SEAS, particularly the coastal waters off Cochin have only recently been studied (Minu et al., 2014; Shaju et al., 2015; Minu et al., 2016) and the in-situ bio-optical data available are meager (Menon et al., 2011). Menon et al. (2006) studied the variability of remote sensing reflectance $\left(R_{\mathrm{rs}}\right)$ along the coastal and northeastern waters of Arabian Sea and reported that CDOM is one of the significant optical constituents making the area optically complex. Tilstone et al. (2013) reported that Chl_ $a$ was maximum during SWM and evaluated the performance of 3 MODIS-Aqua algorithm along coastal shelf waters of eastern Arabian Sea. Seasonal variability of the bio-optical properties along the coastal waters of Cochin is complex and affected by various physical processes and seasonal monsoon. On the other hand, knowledge of the processes responsible for variation in bio-optical properties is a necessary basis for understanding remote sensing data from this area. Sravanthi et al. (2013) have been found a significant correlation $\left(R^{2}=0.62\right)$ between the in-situ Surface Sediment Concentration (SSC) and retrieved SSC from Oceansat-2 along the coastal waters off Cochin. This study further found a high concentration of SSC $(>20 \mathrm{mg} / \mathrm{l})$ in the onshore waters and minimum $(<2 \mathrm{mg} /$ 1) was observed towards the offshore region. Minu et al. (2014) studied the effects of optically active components at a coastal site off Cochin, reported that Chl_ $a$ is the major light absorbing component and described the main source of CDOM as terrestrial during SWM. Recently, Minu et al. (2016) evaluated the performance of the six bio-optical algorithms to retrieve Chl_ $a$ at off Cochin and concluded that the performances of the tested algorithms were found inadequate in the near coastal waters.

To improve the retrieval accuracy of ocean colour components requires a detailed understanding of the mechanisms that regulate the variability of optically active components. Using the in-situ bio-optical data from the coastal waters off Cochin, we examined the seasonal variability of the phytoplankton absorption coefficient, coloured dissolved organic matter absorption coefficient, detritus matter absorption coefficient, chlorophyll $a$, total suspended matter, and diffuse attenuation coefficient. Our bio-optical data representative of the four different seasons namely Spring Inter Monsoon (SIM; March-May), South West Monsoon (SWM; June-September), Fall Inter Monsoon (FIM; October-November) and Winter Monsoon (WM; December-February) were assessed during the present study. Thus, the focus of this study is to characterize the optically active constituents and cause of seasonal and spatial variability of the bio-optical properties along the coastal waters off Cochin.

The specific objectives of this study are (1) to characterize the seasonal and spatial variability in the absorption components and its relationship with physical and biogeochemical variables along the coastal waters off Cochin and explore the source characterization of CDOM. (2) to study the seasonal and spatial variability in phytoplankton absorption coefficient and specific absorption coefficient and its relation with Chlorophyll $a$ concentration and (3) to understand the seasonal variability in the relative contribution of bio-optical components.

\section{Data and methods}

\subsection{Study area}

Cochin Estuary is one of the largest estuarine systems in the south west coast of India, which Joins to the Arabian Sea at two main regions, (i.e., Cochin and Azhikode). The width of Cochin inlet is about $450 \mathrm{~m}$, and Azhikode has a narrow width of $250 \mathrm{~m}$ respectively. Due to anthropogenic activity, Cochin estuary receives $1.04 \times 10^{5} \mathrm{~m}^{3}$ of untreated industrial effluents and $260 \mathrm{~m}^{3}$ of domestic or sewage wastes, which alters the bio-geochemical properties of coastal water off Cochin (Gupta et al., 2016; Sudheesh et al., 2016). The coastal waters off Cochin in SEAS is typical optically complex Case 2 water (Minu et al., 2014). During WM and SWM, seasonally changing West India Coastal Current, (WICC) flowing northward and southward influence the oceanography of coastal waters of SEAS. During SWM coastal waters off Cochin experience significant upwelling and vertical mixing leading to high primary productivity and high suspended sediment concentration (George et al., 2013; Gupta et al., 2016; Shynu et al., 2017). The SIM and FIM exhibit a transitional condition between two monsoons. During WM, the northerly current brings low saline water originating from the Bay of Bengal, which enhances stratification in the upper water column of SEAS. Fig. 1 shows the surface current vectors for SIM, SWM, FIM and WM averaged for the year 2015-2016 and map of locations of sampling stations along the coastal waters off Cochin. Surface water samples were collected from four stations with bathymetric variations. The station $\mathrm{B} 1\left(09^{\circ} 58.178^{\prime} \mathrm{N}, 76^{\circ} 13.328^{\prime} \mathrm{E}\right)$ is located at Barmouth having a depth of $10 \mathrm{~m}$. The Barmouth region is the meeting place where freshwater from Cochin estuary enters into the sea through a single narrow outlet. The Station B2 (09 $\left.58.976 \mathrm{~N}^{\prime}, 76^{\circ} 10.117^{\prime} \mathrm{E}\right)$ has a bathymetric depth of $10 \mathrm{~m}$. The station B3 $\left(09^{\circ} 58.97^{\prime} \mathrm{N}, 76^{\circ}\right.$ $\left.06.149^{\prime} \mathrm{E}\right)$ has a bathymetric depth of $20 \mathrm{~m}$ and station B4 $\left(09^{\circ} 58.523\right.$ $\mathrm{N}^{\prime}, 76^{\circ} 02.747^{\prime} \mathrm{E}$ ) has a bathymetric depth of $30 \mathrm{~m}$ which is the farthest station located from the coast. These stations cover the waters 

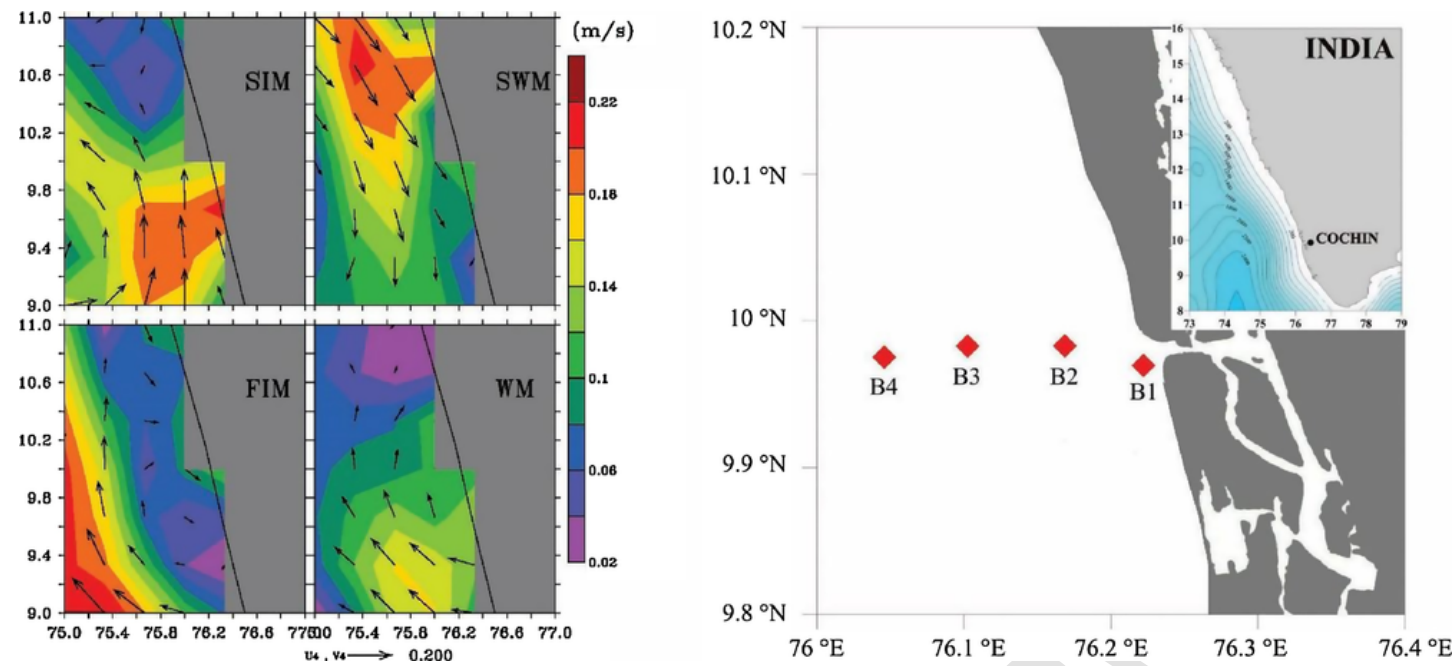

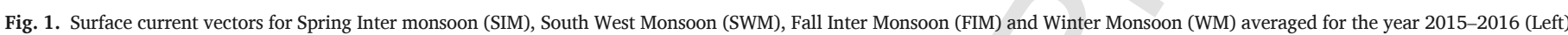
and map of locations of sampling stations along the coastal waters off Cochin (Right).

influenced by a seasonal change in freshwater input, upwelling and other physical properties and the associated change in the biological production (Gupta et al., 2016; George et al., 2013).

\subsection{In-situ measurements}

Monthly cruises were conducted onboard trawler Santa Cruz for one year from March 2015 to February 2016 along the coastal waters off Cochin to study the bio-optical characteristics. Surface water samples were collected from each stations using a 2.51 (General Oceanic, USA) Niskin water sampler. All filtration was done under subdued light conditions, and analyses were done immediately after filtration. Salinity was measured using a hand-held Refractometer (Atago, S/Mill - E, Japan). pH measurement was made using a portable $\mathrm{pH}$ meter (Perkin Elmer, accuracy, \pm 0.01 ) and the meter was calibrated with standards of certified values of $\mathrm{pH}$ corresponding to 4, 7 and 10. Dissolved oxygen was measured according to Winkler's titration methods recommended by (Grasshoff et al., 1983). CDOM absorption coefficients $\left(a_{\mathrm{CDOM}}\right)$, particulate absorption coefficient $\left(a_{\mathrm{p}}\right)$ and detritus $\left(a_{\mathrm{d}}\right)$ for surface water samples were measured using Shimadzu UV-vis spectrophotometer UV-2700. Radiometric measurements were also made, and processing protocol described later in this study.

\subsubsection{In-situ chlorophyll a}

Surface water samples (one to three liters) were collected from each station using Niskin bottles and samples were immediately transported to the laboratory for further analysis. Water samples were filtered through $0.7 \mathrm{~mm}$ Whatman glass fiber filter (GF/F) paper under low vacuum (200 mm $\mathrm{Hg} / \mathrm{vac}$ ) and kept in acetone of $90 \%$ concentration at $0{ }^{\circ} \mathrm{C}$ for $24 \mathrm{~h}$ at dark for the complete extraction. The extracted solution centrifuged for $10-15 \mathrm{~min}$ and the solvent is used to estimate Chl_a concentration using Turner 10 AU fluorometer using Welschmeyer kit (Welschmeyer, 1985) which is calibrated with sigma Chl_a standards.

\subsubsection{CDOM absorption}

Surface water samples for the measurement of CDOM concentration were collected from each station using Niskin bottles and samples were collected in acid-washed, pre-combusted amber coloured borosilicate glass bottles. The bottles are rinsed thrice with the sample before the final collection and stored at $4{ }^{\circ} \mathrm{C}$. Samples collected were immediately transferred to the laboratory at $4{ }^{\circ} \mathrm{C}$ and filtered through $0.2 \mathrm{~mm}$ cellulose nitrate filter paper under low vacuum to remove particulate and suspended sediment materials from the water samples. Before filtra- tion, filtration unit was thoroughly cleaned with distilled water and further rinses with $10 \% \mathrm{HCl}$ followed by copious rinses with distilled water. The filtered samples were allowed to reach the ambient room temperature to avoid the temperature difference between samples and the blank. The absorbance of the filtrate was measured in $10 \mathrm{~cm}$ cuvettes on a Shimadzu UV-vis 2700 spectrophotometer $(400-700 \mathrm{~nm})$ against blank of Milli-Q water. The samples cuvettes and reference cuvettes were rinsed with Methanol, $10 \% \mathrm{HCl}$ and Milli-Q water. Milli-Q water has been used as reference sample.

The CDOM absorption coefficients $\left(a_{\mathrm{CDOM}}(\lambda) \mathrm{m}^{-1}\right)$ at each wavelength were computed from the measured absorbance $\left(\mathrm{A}_{\mathrm{CDOM}}\right)$ or optical density $\left(\mathrm{OD}_{\mathrm{CDOM}}\right)$ resulting from the difference between the sample absorbance and the reference absorbance (Ferrari et al., 1996), and $l_{c}$ as path length of the cuvette (here $0.1 \mathrm{~m}$ ).

$\mathrm{a}_{\mathrm{CDOM}}(\lambda)=\frac{2.3025 \times \mathrm{A}_{\mathrm{CDOM}}(\lambda)}{1_{\mathrm{c}}} \quad\left(\mathrm{m}^{-1}\right)$

The spectral absorption coefficient for CDOM can be expressed by a single exponential model (Kowalczuk and Kaczmarek, 1996)

$a_{\mathrm{CDOM}}(\lambda)=a_{\mathrm{CDOM}}\left(\lambda_{\mathrm{r}}\right) \exp \left[-\mathrm{S}_{\mathrm{CDOM}}\left(\lambda-\lambda_{\mathrm{r}}\right)\right]$

where $\mathrm{S}_{\mathrm{CDOM}}$ is the spectral slope coefficient of $a_{\mathrm{CDOM}}$ spectrum and $\lambda_{\mathrm{r}}$ is the reference wavelength at $440 \mathrm{~nm}$. $\mathrm{S}_{\mathrm{CDOM}}$ was calculated as the slope of the curve resulted by plotting the logarithm of $a_{\mathrm{CDOM}}$ spectrum against wavelength $(\lambda)$. CDOM spectral characteristics and its spectral slope is typically indicative of the CDOM chemical composition (Stedmon and Markager, 2003). The absorption coefficients were corrected for backscattering of small particles and colloids, which pass through filters (Green and Blough, 1994)

$a_{\mathrm{CDOM} \_} \operatorname{corr}(\lambda)=a_{\mathrm{CDOM}}(\lambda)-a_{\mathrm{CDOM}}(700) *(\lambda / 700)$

\subsubsection{Phytoplankton and detritus absorption}

The light absorption properties of the particulate matter, phytoplankton (pigment material) and detritus material (non-pigmented material) measured by the quantitative filter technique (QFT) method (Greg Mitchell and Holm-Hansen, 1991). The surface water samples collected from four different stations were immediately transported to the laboratory and filtered under low vacuum through $0.7 \mathrm{~mm}$ Whatman GF/F glass fiber filters. The absorption spectra of total particulate matter relative to a blank filter saturated with sea-water filtered through $0.2 \mathrm{~mm}$ filter paper were recorded in the wavelength range $400-750 \mathrm{~nm}$ at a resolution of $1 \mathrm{~nm}$ with a Shimadzu UV-2700 double- 
beam spectrophotometer equipped with an integrating sphere. For each of the measured spectra, the optical density at $750 \mathrm{~nm}$ was subtracted from that of the entire spectrum. Optical density of the total suspended matter was corrected for the path length amplification ( $\beta$ effect) and converted into light absorption coefficients by total particulate matter and detritus matter $\left(a_{\mathrm{p}}(\lambda)\right.$ and $\left.a_{\mathrm{d}}(\lambda)\right)$ respectively according to (Cleveland and Weidemann, 1993; Kyewalyanga et al., 1998) as follows:

$a_{\mathrm{p}}(\lambda)=\frac{2.303[\mathrm{ODp}]_{\mathrm{S}}(\lambda)}{\mathrm{V} / \mathrm{S}}\left(\mathrm{m}^{-1}\right)$

$[\mathrm{ODp}]_{\mathrm{s}}(\lambda)=0.378 \mathrm{OD}_{\mathrm{f}}(\lambda)+0.523\left[\mathrm{OD}_{\mathrm{f}}(\lambda)\right]^{2}$

where $[\mathrm{ODp}]_{S}(\lambda)$ is the optical density of total suspended particulate matter, $\mathrm{V}$ is the filtration volume $\left(\mathrm{m}^{3}\right)$ and $\mathrm{S}$ is the filtration area $\left(\mathrm{m}^{2}\right)$. The coefficients 0.378 and 0.523 are the path length amplification factor caused by multiple scattering in the glass fiber filter.

Following the measurement of the total particulate absorption spectrum, the filters were extracted in $100 \%$ methanol following the procedure of (Kishino et al., 1985) and then saturated with filtered seawater and detritus absorption of the filters was measured. These spectra represent absorption by non-methanol-extractable detritus

$a_{\mathrm{d}}(\lambda)=\frac{2.303[\mathrm{ODd}]_{\mathrm{S}}(\lambda)}{\mathrm{V} / \mathrm{S}}\left(\mathrm{m}^{-1}\right)$

Where $[\mathrm{ODd}]_{S}(\lambda)$ is calculated using the same equation as above. The term V and $\mathrm{S}$ stand for the filtration volume $\left(\mathrm{m}^{3}\right)$ and filtration area $\left(\mathrm{m}^{2}\right)$ respectively.

An estimate of phytoplankton component of the total particulate absorption $\left(a_{\mathrm{ph}}(\lambda)\right)$ was then determined by subtracting $a_{\mathrm{d}}(\lambda)$ from $a_{\mathrm{p}}(\lambda)$ (Kishino et al., 1985)

$a_{\mathrm{ph}}(\lambda)=a_{\mathrm{p}}(\lambda)-a_{\mathrm{d}}(\lambda)$

The chlorophyll-specific phytoplankton absorption coefficients $\left(a_{\mathrm{ph}}^{*}\right.$ $(\lambda)$ ) were obtained by normalizing $a_{\mathrm{ph}}(\lambda)$ to the Chl_ $a$ concentration measured by fluorometer.

\subsubsection{Diffuse attenuation coefficient $\left(K_{d}\right)$}

Monthly radiometric properties were measured during 2015-2016 along the Coastal Waters off Cochin. In-water measurements of spectral upwelling radiance $\left(L_{\mathrm{u}}\right)$ and spectral downwelling irradiance $\left(E_{\mathrm{d}}\right)$ were obtained using a Satlantic ${ }^{\mathrm{TM}}$ hyperspectral free fall optical profiler (hyperspectral radiometer (HyperOCRII)) in the wavelength range of 350-800 $\mathrm{nm}$. In-air surface radiance $\left(E_{\mathrm{s}}\right)$ was measured using a deck reference sensor mounted on the top of the ship to avoid shadowing effects during the cast. The radiometer was deployed away from the vessel to avoid ship-induced perturbations and shading (Fargion and Mueller, 2000). The data were recorded using SatView ${ }^{\mathrm{TM}}$ software and processed with Prosoft тм software 7.7.16. When the tilt of the sensor was more than $5^{\circ}$ or the profiling velocity was more than $0.5 \mathrm{~ms}^{-1}$, the data were discarded to ensure the quality of the measurements. The $K_{\mathrm{d}}$ results were used wherever the data were available, and we admit here that at some stations we could not operate the instrument due to the technical issues. We do not have Radiometer data for May 2015 in SIM. During SWM and FIM no $K_{\mathrm{d}}$ value at B1 station for August and November 2015. During WM no $K_{\mathrm{d}}$ value at B2 station in December 2015.

Diffuse attenuation coefficient $\left(K_{d}(\lambda)\right)$ was calculated from the relative variation of the downwelling irradiance $E_{\mathrm{d}}(\lambda, \mathrm{z})$ with depth $\mathrm{z}$. The attenuation of spectral downwelling irradiance $E_{\mathrm{d}}(\lambda, \mathrm{z})$ in units of $\mathrm{mW}$ $\mathrm{cm}^{-2} \mathrm{~nm}^{-1}$ at wavelength $\lambda$, is governed by the Beer-Lambert Law: $E_{d}(\lambda, z)=E_{d}\left(\lambda, 0^{-}\right) \times e^{-K_{d}[\lambda, z] z}$ where $K_{d}(\lambda, z)$ is expressed in per unit meter, averaged over the depth range from just below the sea surface, $0^{-}$, to depth $\mathrm{z}$ in meters.

\subsubsection{Total suspended matter concentration}

Suspended sediments (SS) refers to small solids particles which remain in suspension in water as a colloid or due to the motion of the water. It is used as an indicator of water quality. Total Suspended Matter (TSM) concentration was determined gravimetrically as per the procedure of (Strickland and Parsons, 1972). Seawater samples collected were filtered through pre-weighted Whatman GF/F glass microfiber filter $(0.7 \mu \mathrm{m} ; 47 \mathrm{~mm})$ pre-combusted at $450{ }^{\circ} \mathrm{C}$. After the filtration, the filter paper was dried at $60^{\circ}$ for $24 \mathrm{~h}$ in a clean oven and subsequently reweighed with at least four digits of precision to calculate the correct TSM in $\mathrm{mg} / \mathrm{L}$. TSM was then calculated by using the equation:

$\operatorname{TSM}(m g / L)=(A-B) \times 1000 / C$

where A is the final dried weight of the filter in milligram, B is initial weight of the filter in milligrams, and $\mathrm{C}$ is the volume of water filtered in litres.

\subsubsection{Seasonal variability in water quality parameters along the coastal waters off Cochin}

Table 1 presents the variability in water quality and optical properties during SIM, SWM, FIM and WM along the coastal waters off Cochin. The Barmouth region (B1 station) was influenced by freshwater discharge from Cochin estuary during SWM (Gupta et al., 2016; Sudheesh et al., 2016) and accordingly in our study, salinity showed a lower value at B1 station ranged between 13.43-31.62 (psu) with an average value of $22.53 \pm 12.87$ (psu) during SWM and similarly salinity showed a higher value at B3 station ranged between 33.62-34.53 (psu) with an average value of $33.93 \pm 0.52$ (psu) during WM. The value of $\mathrm{pH}$ was higher at $\mathrm{B} 4$ station varied from 8.2 to 8.3 with an average value of $8.25 \pm 0.07$ during FIM and showed a lower value at B1 station varied from 7.5 to 7.7 with an average value of $7.57 \pm 0.12$ during SIM. The dissolved oxygen concentration showed a higher value at B4 station ranged from 6.4 to $7.4\left(\mathrm{mgO}_{2} / 1\right)$ with an average value of $6.9 \pm 0.71\left(\mathrm{mgO}_{2} / \mathrm{l}\right)$ and showed a lower value at $\mathrm{B} 3$ station ranged between $1.35-7\left(\mathrm{mgO}_{2} / \mathrm{l}\right)$ with an average of $4.18 \pm 3.99\left(\mathrm{mgO}_{2} / \mathrm{l}\right)$ during SWM. The coastal water off Cochin is highly productive during SWM due to coastal upwelling (Sudheesh et al., 2017). Thus during our study, a higher value of Chl_ $a$ concentration ranged from 6.40 to 11.65 $\left(\mathrm{mg} \mathrm{m}^{-3}\right)$ found at station B3 with an average value of $9.03 \pm 0.71$ $\left(\mathrm{mg} \mathrm{m}^{-3}\right)$ during SWM and showed a lower value at B4 station ranged from 0.337 to $1.57\left(\mathrm{mg} \mathrm{m}^{-3}\right)$ with an average value of $0.916 \pm 0.620$ $\left(\mathrm{mg} \mathrm{m}^{-3}\right.$ ) during SIM. TSM showed a higher value at station B1 ranged from 39.4 to $100(\mathrm{mg} / \mathrm{l})$ with an average value of $64.09 \pm 31.83(\mathrm{mg} /$ 1) during $\mathrm{WM}$, and showed a lower value at station $B 4$, ranged from 0.7 to $34(\mathrm{mg} / \mathrm{l})$ with an average value of $14.23 \pm 17.50(\mathrm{mg} / \mathrm{l})$ during SIM. The value of $a_{\mathrm{ph}}$ (443) was higher at station B1 ranged from 0.055 to $0.177\left(\mathrm{~m}^{-1}\right)$ with an average value of $0.106 \pm 0.064\left(\mathrm{~m}^{-1}\right)$ during SIM and lower value at station B3 ranged from 0.009 to 0.028 $\left(\mathrm{m}^{-1}\right)$ with an average value of $0.019 \pm 0.013\left(\mathrm{~m}^{-1}\right)$ during FIM. Equivalently, $a_{\mathrm{d}}$ (443) showed a higher value at B1 station ranged from 0.051 to $1.45\left(\mathrm{~m}^{-1}\right)$ with an average value of $0.75 \pm 0.99\left(\mathrm{~m}^{-1}\right)$ during FIM and showed lower value at station B4 ranged from 0.011 to $0.037\left(\mathrm{~m}^{-1}\right)$ with an average value of $0.028 \pm 0.015\left(\mathrm{~m}^{-1}\right)$ during SIM. The $a_{\mathrm{CDOM}}$ (443) showed a higher value at $\mathrm{B} 1$ station ranged from 0.07 to $0.194\left(\mathrm{~m}^{-1}\right)$ with an average value of $0.13 \pm 0.09\left(\mathrm{~m}^{-1}\right)$ during SWM and showed a lower value at B4 station ranged from 0.01 to 0.07 $\left(\mathrm{m}^{-1}\right)$ with an average value of $0.035 \pm 0.031\left(\mathrm{~m}^{-1}\right)$ during WM. Similarly, $S_{\mathrm{CDOM}}$ showed a higher value at B1 station ranged from 0.016 to $0.020\left(\mathrm{~nm}^{-1}\right)$ with an average value of $0.018 \pm 0.002\left(\mathrm{~nm}^{-1}\right)$ during SWM and showed a lower value at B4 station ranged from 0.004 to 
Table 1

The water quality and optical properties (average \pm standard deviation) during Spring Inter Monsoon, South West Monsoon, Fall Inter Monsoon and Winter Monsoon along the coastal waters off Cochin.

\begin{tabular}{|c|c|c|c|c|c|c|c|c|c|c|}
\hline Seasons & Stations & Salinity (psu) & $\mathrm{pH}$ & $\mathrm{DO}\left(\mathrm{mgO}_{2} / \mathrm{l}\right)$ & Chl_a $a\left(\mathrm{mg} \mathrm{m}^{-3}\right)$ & $\operatorname{TSM}(\mathrm{mg} / \mathrm{l})$ & $a_{\mathrm{ph}} 443\left(\mathrm{~m}^{-1}\right)$ & $a_{\mathrm{d}} 443\left(\mathrm{~m}^{-1}\right)$ & $a_{\mathrm{CDOM}} 443\left(\mathrm{~m}^{-1}\right)$ & $S_{\mathrm{CDOM}}\left(\mathrm{nm}^{-1}\right)$ \\
\hline \multirow[t]{4}{*}{ SIM } & B1 & $29.77 \pm 1.49$ & $7.57 \pm 0.12$ & $5.87 \pm 0.47$ & $4.57 \pm 1.47$ & $12.67 \pm 6.03$ & $0.106 \pm 0.064$ & $0.28 \pm 0.08$ & $0.14 \pm 0.01$ & $0.014 \pm 0.002$ \\
\hline & B2 & $32.63 \pm 1.18$ & $7.7 \pm 0.2$ & $5.36 \pm 1.81$ & $1.63 \pm 0.91$ & $15.67 \pm 18.91$ & $0.057 \pm 0.064$ & $0.15 \pm 0.09$ & $0.064 \pm 0.059$ & $0.01 \pm 0.005$ \\
\hline & B3 & $33.56 \pm 0.29$ & $7.67 \pm 0.31$ & $4.8 \pm 1.39$ & $0.89 \pm 0.87$ & $13.97 \pm 14.16$ & $0.027 \pm 0.013$ & $0.054 \pm 0.043$ & $0.039 \pm 0.019$ & $0.011 \pm 0.005$ \\
\hline & B4 & $33.79 \pm 0.44$ & $7.67 \pm 0.38$ & $6.29 \pm 0.65$ & $0.92 \pm 0.62$ & $14.24 \pm 17.51$ & $0.030 \pm 0.002$ & $0.028 \pm 0.015$ & $0.029 \pm 0.002$ & $0.01 \pm 0.001$ \\
\hline \multirow[t]{4}{*}{ SWM } & B1 & $22.53 \pm 12.87$ & $8 \pm 0.29$ & $5.2 \pm 1.69$ & $3.74 \pm 1.17$ & $19.5 \pm 0.71$ & $0.066 \pm 0.017$ & $0.44 \pm 0.35$ & $0.14 \pm 0.09$ & $0.018 \pm 0.002$ \\
\hline & B2 & $31.25 \pm 1.85$ & $7.95 \pm 0.08$ & $4.9 \pm 2.41$ & $7.43 \pm 5.98$ & $17 \pm 1.42$ & $0.113 \pm 0.066$ & $0.23 \pm 0.11$ & $0.11 \pm 0.01$ & $0.014 \pm 0.001$ \\
\hline & B3 & $31.04 \pm 2.64$ & $8.05 \pm 0.07$ & $4.18 \pm 3.99$ & $9.03 \pm 3.72$ & $9.92 \pm 7.66$ & $0.106 \pm 0.040$ & $0.18 \pm 0.05$ & $0.09 \pm 0.01$ & $0.015 \pm 0.002$ \\
\hline & B4 & $32.33 \pm 1.09$ & $8.15 \pm 0.07$ & $6.9 \pm 0.71$ & $6.07 \pm 2.31$ & $14.07 \pm 10.28$ & $0.108 \pm 0.034$ & $0.16 \pm 0.03$ & $0.11 \pm 0.006$ & $0.013 \pm 0.001$ \\
\hline \multirow[t]{4}{*}{ FIM } & B1 & $27.85 \pm 4.28$ & $7.85 \pm 0.22$ & $4.8 \pm 1.14$ & $1.81 \pm 0.42$ & $29.33 \pm 10.37$ & $0.083 \pm 0.090$ & $0.76 \pm 0.99$ & $0.12 \pm 0.08$ & $0.017 \pm 0.002$ \\
\hline & B2 & $33.15 \pm 0.32$ & $8.15 \pm 0.07$ & $6 \pm 0.57$ & $1.12 \pm 1.05$ & $15.55 \pm 7.71$ & $0.027 \pm 0.009$ & $0.080 \pm 0.003$ & $0.088 \pm 0.054$ & $0.014 \pm 0.001$ \\
\hline & B3 & $32.94 \pm 1.40$ & $8.1 \pm 0.15$ & $6.1 \pm 0.43$ & $0.68 \pm 0.36$ & $20.5 \pm 7.78$ & $0.019 \pm 0.013$ & $0.031 \pm 0.023$ & $0.031 \pm 0.007$ & $0.013 \pm 0.004$ \\
\hline & B4 & $33.28 \pm 0.58$ & $8.25 \pm 0.07$ & $6.3 \pm 0.15$ & $0.83 \pm 0.54$ & $10.1 \pm 1.56$ & $0.021 \pm 0.010$ & $0.034 \pm 0.004$ & $0.031 \pm 0.007$ & $0.013 \pm 0.001$ \\
\hline \multirow[t]{4}{*}{ WM } & B1 & $33.06 \pm 0.45$ & $7.87 \pm 0.41$ & $6.4 \pm 0.4$ & $3.05 \pm 2.09$ & $64.09 \pm 31.83$ & $0.076 \pm 0.028$ & $0.49 \pm 0.11$ & $0.065 \pm 0.025$ & $0.016 \pm 0.001$ \\
\hline & B2 & $33.55 \pm 0.32$ & $8 \pm 0.27$ & $6.14 \pm 1.0$ & $1.98 \pm 1.64$ & $46.29 \pm 20.59$ & $0.072 \pm 0.033$ & $0.52 \pm 0.51$ & $0.040 \pm 0.01$ & $0.012 \pm 0.001$ \\
\hline & B3 & $33.93 \pm 0.52$ & $8.07 \pm 0.16$ & $6.47 \pm 0.31$ & $0.94 \pm 0.55$ & $29.15 \pm 14.67$ & $0.044 \pm 0.008$ & $0.11 \pm 0.06$ & $0.032 \pm 0.033$ & $0.009 \pm 0.001$ \\
\hline & B4 & $33.95 \pm 0.52$ & $8.24 \pm 0.06$ & $6.82 \pm 0.03$ & $0.91 \pm 0.48$ & $30.53 \pm 7.29$ & $0.036 \pm 0.032$ & $0.083 \pm 0.071$ & $0.035 \pm 0.031$ & $0.008 \pm 0.004$ \\
\hline
\end{tabular}


$0.011\left(\mathrm{~nm}^{-1}\right)$ with an average value of $0.008 \pm 0.004\left(\mathrm{~nm}^{-1}\right)$ during WM.

\section{Results and discussion}

\subsection{Seasonal variability in absorption components}

The samples were collected from four different seasons namely SIM, SWM, FIM, and WM to analyse the seasonal variability in bio-optical parameters. To incorporate the spatial variation, samples were collected from different bathymetric regions. The Barmouth region was dominated with highly turbid waters during the entire period of study. This study shows a high variability in absorption components along the coastal waters off Cochin. Chl_ $a$ concentration and $a_{\mathrm{CDOM}}$ (443) showed higher values during SWM, where Chl_ $a$ concentration varied from 2.91 to $11.66 \mathrm{mg} \mathrm{m}^{-3}$ with an average value of $6.57 \pm 3.52 \mathrm{mg} \mathrm{m}^{-3}$ and $a_{\mathrm{CDOM}}$ (443) varied from 0.066 to $0.185 \mathrm{~m}^{-1}$ with an average value of $0.107 \pm 0.035 \mathrm{~m}^{-1}$. TSM concentration was higher during WM, ranged between $19.23-100 \mathrm{mg} / \mathrm{l}$ with an average value of $42.52 \pm 22.99 \mathrm{mg} /$ 1. To understand the variability of optically active components (i.e., Chl_a, $a_{\mathrm{CDOM}}$ (443), and TSM) data were plotted against each other for the different seasons SIM, SWM, FIM, and WM as shown in (Fig. 2). The regression coefficient derived between Chl_a, absorption by CDOM at 443 and TSM during SIM, SWM, FIM and WM are summarized in (Table 2). It was found that during SIM a significant relationship exists between Chl_ $a$ and $a_{\mathrm{CDOM}}(443)\left(\mathrm{R}^{2}=0.73\right.$, Table 2). Whereas, a poor relationship was observed between Chl_ $a$ vs TSM and TSM vs $a_{\text {CDOM }}$ (443) with an $\mathrm{R}^{2}$ value of 0.09 and 0.23 (Table 2). During SWM, no significant relationship was observed between Chl_ $a$,
$a_{\mathrm{CDOM}}(443)$, and TSM (Table 2). During SWM period $a_{\mathrm{CDOM}}$ (443) and Chl_ $a$ showed an increasing trend from B1 station to B4 station which could be due to the high nutrients brought about by upwelling process associated with SWM. (Tilstone et al., 2013). Among the four seasons, Chl_a concentration was higher during SWM in all the stations except Barmouth. During FIM a significant relationship was found between Chl_ $a$ vs $a_{\mathrm{CDOM}}$ (443) with an $\mathrm{R}^{2}$ value of 0.68 , while during WM, no significant relationship was found between Chl_ $a, a_{\mathrm{CDOM}}$ (443) and TSM. During the entire period of the study (seasonally and spatially), a weak relationship existed between Chl_ $a$ and TSM as well as TSM and $a_{\mathrm{CDOM}}$ (443) which could be due to the large contribution of inorganic particles in the total suspended matter discharged from Cochin estuary (Sudheesh et al., 2016).

\subsection{CDOM absorption and source characterization}

Fig. 3 presents frequency distributions of the $\mathrm{S}_{\mathrm{CDOM}}$ overlaid with normal distribution curve. The value of $\mathrm{S}_{\mathrm{CDOM}}$ varied from 0.003 to $0.020 \mathrm{~nm}^{-1}$, its apparently shows $\mathrm{S}_{\mathrm{CDOM}}$ was highly distributed between the range of $0.012-0.014 \mathrm{~nm}^{-1}$. The statistics of $a_{\mathrm{CDOM}}$ (443) and $\mathrm{S}_{\mathrm{CDOM}}$ during SIM, SWM, FM, and WM are shown in Table 3. During SIM, average values of salinity and $\mathrm{S}_{\mathrm{CDOM}}$ was $32.43 \pm 1.86$ psu and $0.012 \pm 0.004 \mathrm{~nm}^{-1}$ respectively. Salinity was high (34.46 psu) at $\mathrm{B} 4$ station and low (13.43 psu) at $\mathrm{B} 1$ station, whereas $\mathrm{S}_{\mathrm{CDOM}}$ was maximum $\left(0.020 \mathrm{~nm}^{-1}\right)$ at $\mathrm{B} 1$ station and minimum $\left(0.004 \mathrm{~nm}^{-1}\right)$ at B4 station. During SWM, salinity and $\mathrm{S}_{\mathrm{CDOM}}$ varied with an average value of $29.28 \pm 6.55 \mathrm{psu}$ and $0.015 \pm 0.003 \mathrm{~nm}^{-1}$ respectively. During SWM, the inverse relationship between salinity and $\mathrm{S}_{\mathrm{CDOM}}$ were shown with maximum salinity (33.10 psu) at $\mathrm{B} 1$ station and minimum $\mathrm{S}_{\mathrm{CDOM}}$
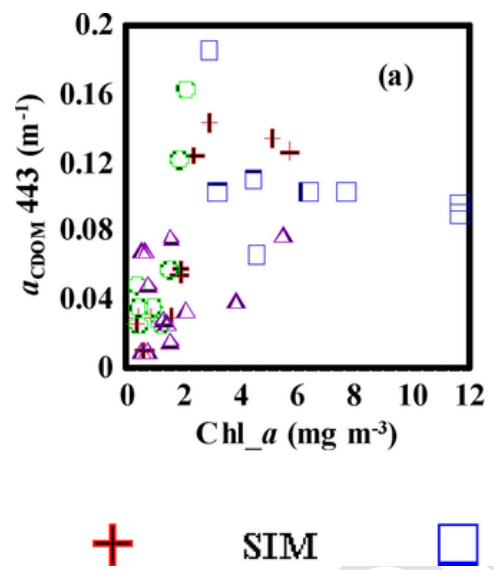
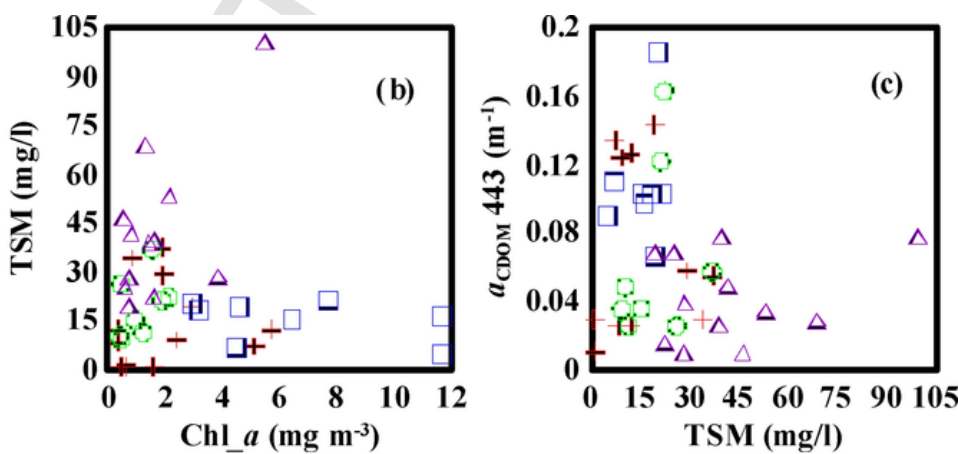

SWM
FIM
WM

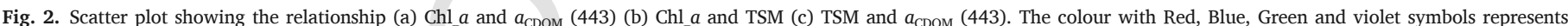

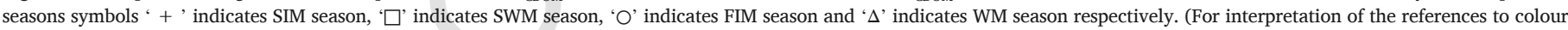
in this figure legend, the reader is referred to the web version of this article.)

Table 2

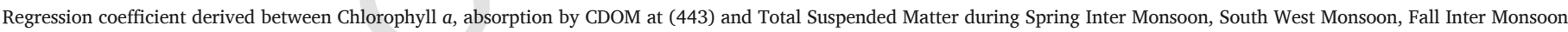
and Winter Monsoon along the coastal waters off Cochin.

\begin{tabular}{|c|c|c|c|c|c|c|}
\hline Seasons & Parameters & $\mathrm{R}^{2}$ & $\mathrm{n}$ & Regression type & Slope & Intercept \\
\hline \multirow[t]{6}{*}{ SIM } & Chl_ $a$ vs $a_{\mathrm{CDOM}}(443)$ & 0.73 & 12 & Linear & 0.024 & 0.018 \\
\hline & Chl_ $a$ vs TSM & 0.09 & 12 & Power & 6.67 & 0.417 \\
\hline & TSM vs $a_{\mathrm{CDOM}}(443)$ & 0.23 & 12 & Power & 0.027 & 0.285 \\
\hline & Chl_ $a$ vs $a_{\mathrm{CDOM}}(443)$ & 0.19 & 8 & Power & 0.153 & -0.225 \\
\hline & Chl_ $a$ vs TSM & 0.16 & 8 & Linear & -0.225 & 9.96 \\
\hline & TSM vs $a_{\mathrm{CDOM}}(443)$ & 0.05 & 8 & Power & 0.001 & 0.087 \\
\hline \multirow[t]{3}{*}{ FIM } & Chl_ $a$ vs $a_{\mathrm{CDOM}}$ (443) & 0.68 & 8 & Linear & 0.061 & -0.005 \\
\hline & Chl_ $a$ vs TSM & 0.26 & 8 & Power & 17.12 & 0.360 \\
\hline & TSM vs $a_{\mathrm{CDOM}}(443)$ & 0.13 & 8 & Power & 0.013 & 0.501 \\
\hline \multirow[t]{3}{*}{ WM } & Chl_ $a$ vs $a_{\mathrm{CDOM}}$ (443) & 0.11 & 12 & Linear & 0.006 & 0.033 \\
\hline & Chl_ $a$ vs TSM & 0.39 & 12 & Linear & 0.041 & -0.029 \\
\hline & TSM vs $a_{\mathrm{CDOM}}(443)$ & 0.05 & 12 & Linear & 0.0002 & 0.032 \\
\hline
\end{tabular}




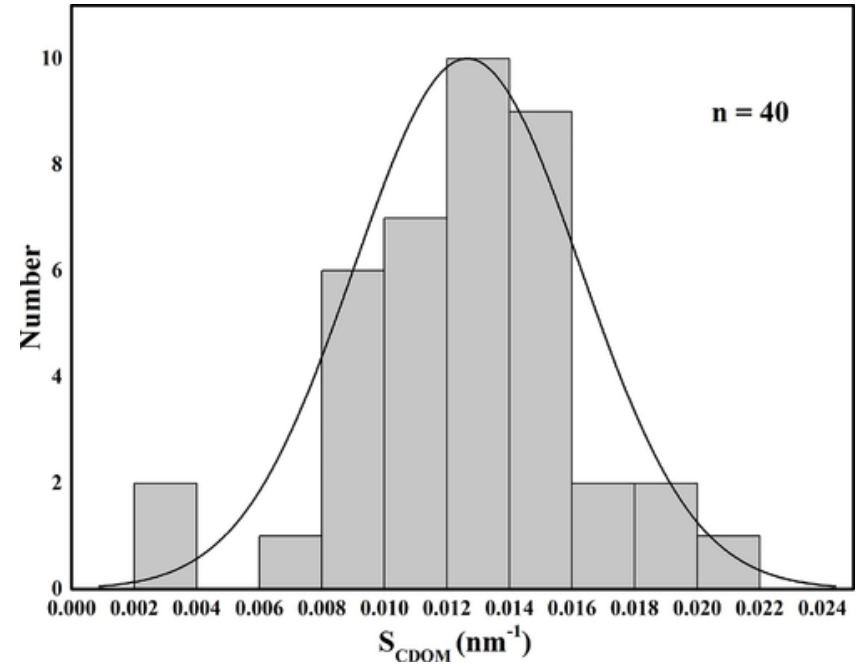

Fig. 3. Frequency distribution curve of $\mathrm{S}_{\mathrm{CDOM}}$ of the CDOM absorption spectrum.

$\left(0.013 \mathrm{~nm}^{-1}\right)$ at station $\mathrm{B} 4$. The average value of salinity and $\mathrm{S}_{\mathrm{CDOM}}$ $31.80 \pm 2.98 \mathrm{psu}$ and $0.015 \pm 0.003 \mathrm{~nm}^{-1}$ was observed during FIM. Again an inverse relationship was found between the salinity and $\mathrm{S}_{\mathrm{CDOM}}$, whereas at station B3 with maximum salinity (33.93 psu) coincides with minimum $\mathrm{S}_{\mathrm{CDOM}}\left(0.009 \mathrm{~nm}^{-1}\right)$ and the minimum salinity $(24.82$ $\mathrm{psu})$ at station $\mathrm{B} 1$ with maximum value of $\mathrm{S}_{\mathrm{CDOM}}\left(0.015 \mathrm{~nm}^{-1}\right)$. During WM, average salinity was $33.62 \pm 0.545 \mathrm{psu}, \mathrm{S}_{\mathrm{CDOM}}$ was highly variable during WM with a mean value of $0.012 \pm 0.005 \mathrm{~nm}^{-1}$. Salinity showed higher value (34.53 psu) at B3 station and lower value (32.54 $\mathrm{psu})$ at $\mathrm{B} 1$ station, whereas $\mathrm{S}_{\mathrm{CDOM}}$ showed higher value $\left(0.020 \mathrm{~nm}^{-1}\right)$ at B1 station and lower value $\left(0.003 \mathrm{~nm}^{-1}\right)$ at B4 sta- tion. The scatter plot and logarithmic regression between $a_{\mathrm{CDOM}}$ (443) vs. $\mathrm{S}_{\mathrm{CDOM}}$ during SIM, SWM, FIM, and WM are shown in (Fig. 5). During SIM a significant relationship was observed between $a_{\mathrm{CDOM}}$ (443) and $\mathrm{S}_{\mathrm{CDOM}}$ with an $\mathrm{R}^{2}$ value of 0.61 and no significant relationship was observed among SWM, FIM, and WM. The absorption by $S_{\text {CDOM }}$ depends both on the wavelength intervals used for fitting and the fitting method (Nima et al., 2016). During WM (Fig. 5d), it was observed that the values of $a_{\mathrm{CDOM}}$ (443) $\mathrm{m}^{-1}$ was lower corresponding to the higher $\mathrm{S}_{\mathrm{CDOM}}\left(\mathrm{nm}^{-1}\right)$. This could be due to the photo-bleaching of dissolved organic matter, where high molecular weight compounds are converted to low molecular weight compounds by the action of incoming solar light (Matsuoka et al., 2015). When considering spatially, the relationship between Chl_ $a$ and $a_{\mathrm{CDOM}}(443)$ was linearly correlated at the surface layers of B3 and B4 station with an $\mathrm{R}^{2}$ value of 0.59 and 0.66 respectively. It indicates that the origin of CDOM was from the degradation of phytoplankton biomass at the station away from the coast. This relationship has been reported in many of the coastal waters and lakes (Tilstone et al., 2013; Riddick et al., 2015). However, this relationship does not exist in the surface waters of B1 and B2 station, because of those stations with their proximity to the estuary, receives a significant amount of riverine discharge, which contributes to the CDOM content in these waters. During the entire period of the study, it was observed that $\mathrm{S}_{\mathrm{CDOM}}$ decreased from Barmouth station to the offshore regions. The relative increase of $\mathrm{S}_{\mathrm{CDOM}}$ in $\mathrm{B} 1$ station could be due to the freshwater discharge from the Cochin estuary.

The linear regression results between Salinity versus $a_{\mathrm{CDOM}}$ (443) during SIM, SWM, FIM, and WM are shown in the (Fig. 4). During SIM a significant relationship existed between $a_{\mathrm{CDOM}}$ (443) and salinity $\left(\mathrm{R}^{2}=0.81\right.$, Fig. $\left.4 \mathrm{a}\right)$ as well as $a_{\mathrm{CDOM}}$ (443) and Chl_ $a\left(\mathrm{R}^{2}=0.73\right.$, Table 2) which indicates that both freshwater inputs and breakdown of phytoplankton cells determines the spatial distribution of $a_{\mathrm{CDOM}}$ (443). During SWM, a significant relationship existed between $a_{\mathrm{CDOM}}$ (443)

Table 3

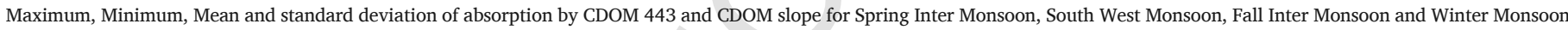
along the coastal waters off Cochin.

\begin{tabular}{|c|c|c|c|c|c|c|c|c|}
\hline & \multicolumn{4}{|c|}{$a_{\mathrm{CDOM}} 443\left(\mathrm{~m}^{-1}\right)$} & \multicolumn{4}{|c|}{$\mathrm{S}_{\mathrm{CDOM}}\left(\mathrm{nm}^{-1}\right)$} \\
\hline & MAX & MIN & MEAN & STD & MAX & MIN & MEAN & STD \\
\hline SIM & 0.143 & 0.009 & 0.066 & 0.051 & 0.016 & 0.003 & 0.012 & 0.004 \\
\hline SWM & 0.185 & 0.067 & 0.107 & 0.035 & 0.019 & 0.013 & 0.014 & 0.002 \\
\hline FIM & 0.163 & 0.026 & 0.064 & 0.051 & 0.018 & 0.009 & 0.014 & 0.002 \\
\hline WM & 0.077 & 0.009 & 0.042 & 0.026 & 0.020 & 0.004 & 0.012 & 0.005 \\
\hline
\end{tabular}
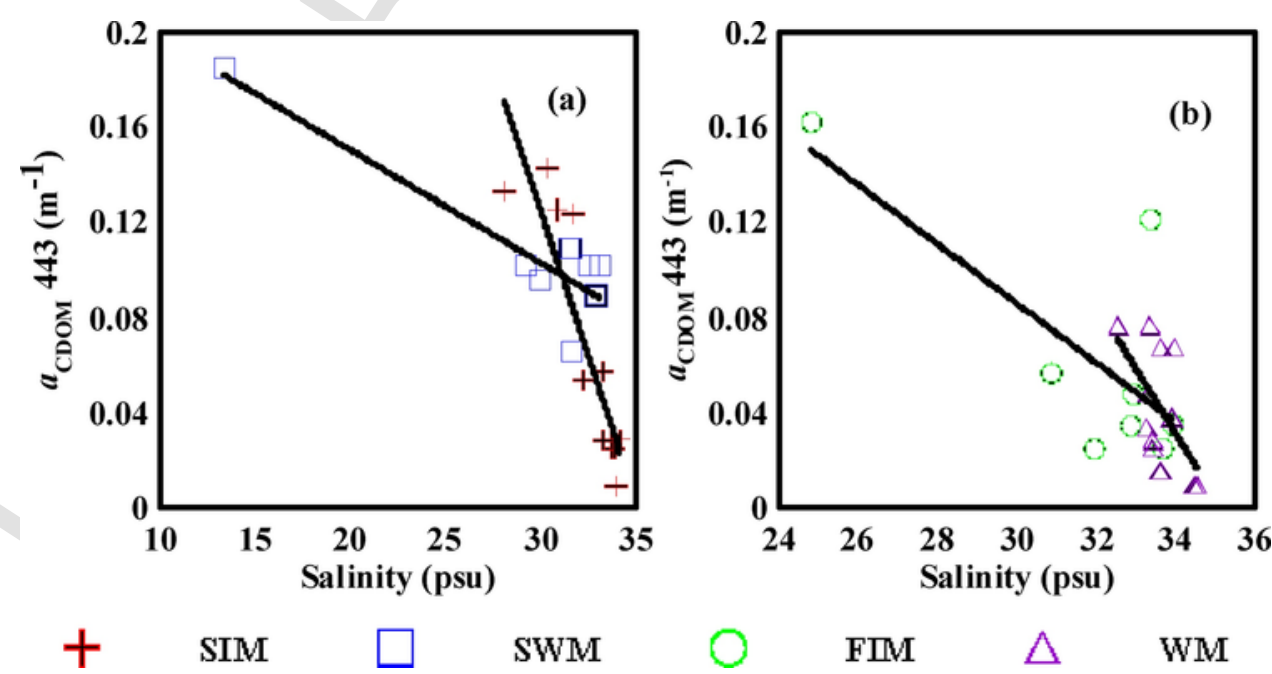

FIM

WM

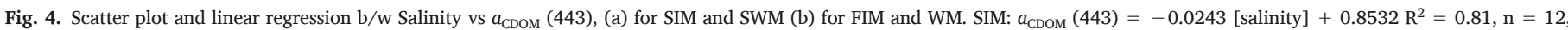

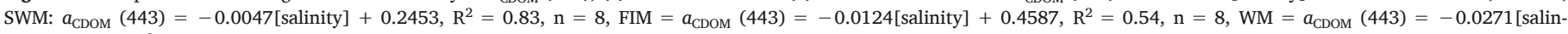
ity $+0.9528, \mathrm{R}^{2}=0.34, \mathrm{n}=12$. 

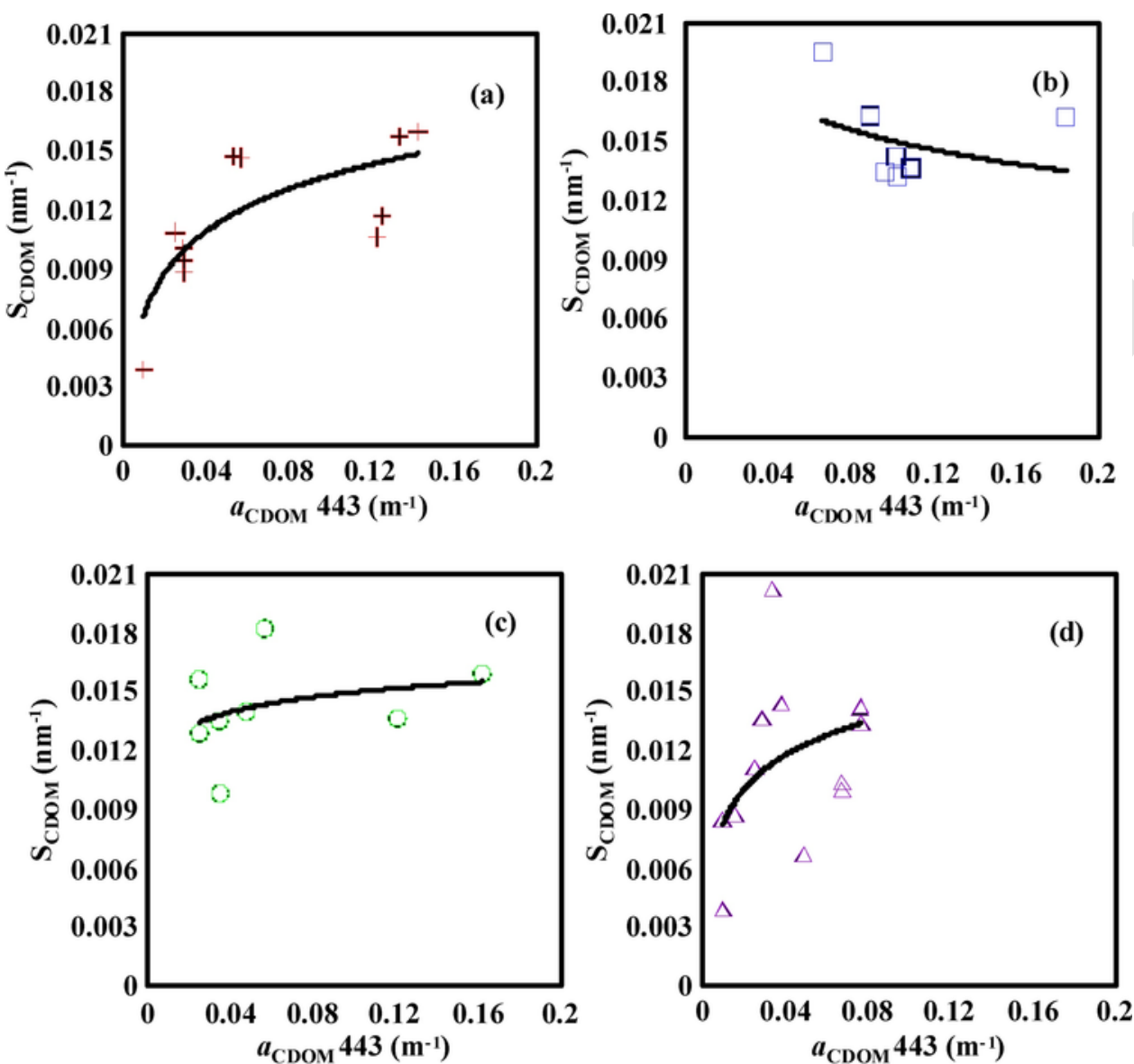

\section{$+\operatorname{SIM} \quad \square \quad$ SWM $\quad$ S FIM $\triangle \quad$ WM}

Fig. 5. Scatter plot and logarithmic regression between vs $a_{\mathrm{CDOM}}(443)$ and $\mathrm{S}_{\mathrm{CDOM}}$ (a) for SIM (b) and SWM (c) for FIM and (d) for WM. SIM: $\mathrm{S}_{\mathrm{CDOM}}=0.0031 * \log \left[\mathrm{a}_{\mathrm{CDOM}}(443)\right]+0.0209$, $\mathrm{R}^{2}=0.61, \quad \mathrm{n}=12, \quad$ SWM: $\quad \mathrm{S}_{\mathrm{CDOM}}=-0.002 * \log \left[\mathrm{a}_{\mathrm{CDOM}}(443)\right]+0.0093, \quad \mathrm{R}^{2}=0.10, \quad \mathrm{n}=8, \quad$ FIM: $\quad \mathrm{S}_{\mathrm{CDOM}}=0.0011 * \log \left[a_{\mathrm{CDOM}}(443)\right]+0.0175, \quad \mathrm{R}^{2}=0.09, \quad \mathrm{n}=8, \quad \mathrm{WM}:$ $\mathrm{S}_{\mathrm{CDOM}}=0.0025 * \log \left[a_{\mathrm{CDOM}}(443)\right]+0.0198, \mathrm{R}^{2}=0.19, \mathrm{n}=12$.

and salinity with an $\mathrm{R}^{2}$ value 0.83 (Fig. 4a). During SWM even though the Chl_ $a$ concentration was higher there was no relationship between Chl $a$ and $a_{\mathrm{CDOM}}$ (443). It confirms that the major source of CDOM during this season was driven by the terrestrial source or from the upwelled water (Tilstone et al., 2013). Conversely, during FIM, only a moderate relationship was observed between $a_{\mathrm{CDOM}}$ (443) and salinity $\left(\mathrm{R}^{2}=0.54\right.$; Fig. $\left.4 \mathrm{~b}\right)$ where as $a_{\mathrm{CDOM}}(443)$ was well correlated with Chl_ $a\left(\mathrm{R}^{2}=0.68\right.$; Table 2$)$ depicting the major source of CDOM as disintegrated products of phytoplankton. This observation was also reported by (Menon et al., 2011). During WM no significant relation observed between Chl_ $a$ and $a_{\mathrm{CDOM}}(443)\left(\mathrm{R}^{2}=0.11\right.$, Table 2$)$ as well as with $a_{\text {CDOM }}(443)$ and salinity $\left(\mathrm{R}^{2}=0.34\right.$; Fig. $\left.4 \mathrm{~b}\right)$. The reason behind the insignificant relation during WM could be because microbial degradation of DOC as the major precursor source of CDOM in the water column, and also photo-degradation might affect the absorption characteristic of CDOM, which is visible from Fig. 5d (Menon et al., 2011; Hansen et al., 2016; Matsuoka et al., 2015).

\subsection{Variability in phytoplankton absorption $\left(a_{p h}(\lambda)\right)$}

The ratio of phytoplankton absorption coefficient at $a_{\mathrm{ph}}(443) /\left(a_{\mathrm{ph}}\right)$ 670 as plotted against Chl_a concentration is shown in Fig. 6 . The ratio of $a_{\mathrm{ph}}(443) / a_{\mathrm{ph}}(670)$ ranged from 0.876 to $6.01 \mathrm{~m}^{-1}$ with an average value of $2.57 \pm 0.943 \mathrm{~m}^{-1}$. The higher $a_{\mathrm{ph}}(443) / a_{\mathrm{ph}}(670)$ ratio was observed at Chl_ $a$ concentration less than $2 \mathrm{mg} \mathrm{m}^{-3}$. When the concentration of Chl $a$ above $2.0 \mathrm{mg} \mathrm{m}^{-3}$, there was no corresponding in-

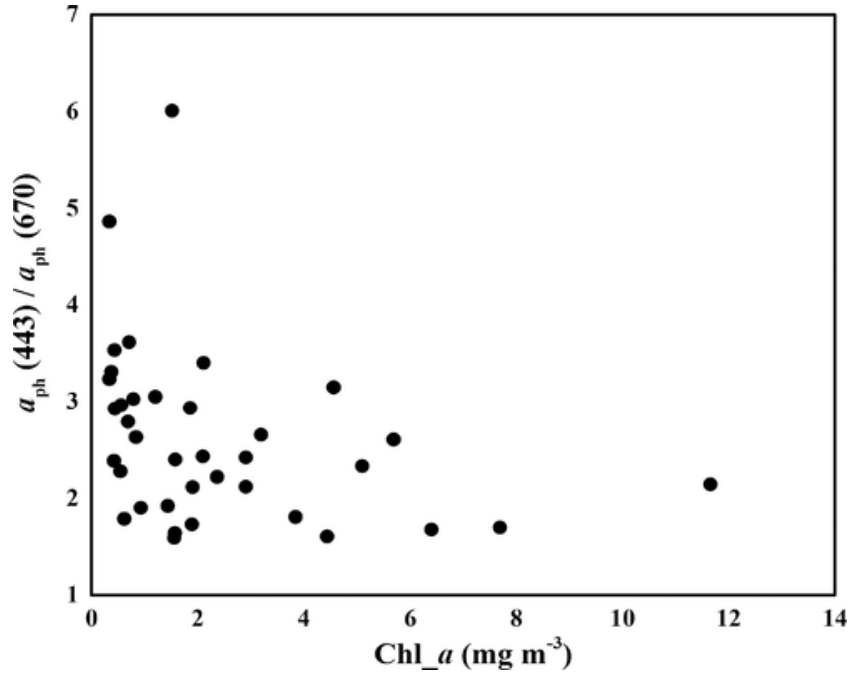

Fig. 6. Variation of $a_{\mathrm{ph}}(443) / a_{\mathrm{ph}}(670)$ as a function of chlorophyll $a$ concentration along the coastal waters off Cochin.

crease in the ratio of absorption coefficient. The observed absorption coefficient was a non-linear function of Chl_ $a$ concentration, this non linearity between Chl_ $a$ and ration of $a_{\mathrm{ph}}(443) / a_{\mathrm{ph}}(670)$ has been in- 
vestigated in many of the coastal waters, which could be due to the intercellular composition of phytoplankton pigment and pigment packaging effect (Shaju et al., 2015; Matsuoka et al., 2011; Riddick et al., 2015).

The relationship between Chl $a$ with $a_{\mathrm{ph}}$ (443), $a_{\mathrm{ph}}(670), a_{\mathrm{ph}}^{*}(443)$ and $a^{*}{ }_{\text {ph }}$ (670) during SIM, SWM, FIM, and WM were shown in (Table 4). During SIM, the results indicated a significant relationship exists between Chl $a$ and $a_{\mathrm{ph}}(443)$ and $a_{\mathrm{ph}}(670)$ with an $\mathrm{R}^{2}$ value of 0.65 and 0.78 respectively (Table 4), while there was no significant relationship between Chl_ $a$ and $a^{*}{ }_{\mathrm{ph}}$ (443) and $a_{\mathrm{ph}}^{*}$ (670). Large variation was observed in the value of $a_{\mathrm{ph}}$ (443), $a^{*}$ ph (443) and $a_{\mathrm{ph}}^{*}$ (670) during SIM, with the average value of $0.055 \pm 0.051 \mathrm{~m}^{-1}, 0.038 \pm 0.031 \mathrm{~m}^{2} \mathrm{mg}^{-1}$ and $0.014 \pm 0.008 \mathrm{~m}^{2} \mathrm{mg}^{-1}$ respectively. During SWM, a significant relationship was found between Chl_ $a$ and $a_{\mathrm{ph}}$ (443), $a_{\mathrm{ph}}$ (670) and $a^{*}{ }_{\mathrm{ph}}$ (443) with an $\mathrm{R}^{2}$ value $0.89,0.94$ and 0.65 respectively (Table 4), whereas no significant relationship was observed between Chl_ $a$ and $a_{\mathrm{ph}}^{*}(670)$. However, $a_{\mathrm{ph}}$ (670) was highly variable during SWM with an average value of $0.054 \pm 0.024 \mathrm{~m}^{-1}$. Chl_ $a$ concentration was also highly variable during SWM with an average value of $6.57 \pm 3.52 \mathrm{mg} \mathrm{m}^{-3}$. During FIM a significant relationship occurred between $a^{*}$ ph (670) versus Chl_ $a$ with an $\mathrm{R}^{2}$ value of 0.68 (Table 4). During WM a significant relationship was observed between $a$ ph (670) versus Chl_ $a$ with an $\mathrm{R}^{2}$ value of 0.69 while a reasonable relationship was found between $a_{\mathrm{ph}}$ (443) versus Chl_a with an $\mathrm{R}^{2}$ value of 0.52 respectively. During SIM and SWM $a_{\mathrm{ph}}$ (443) and (670) nm was strongly correlated with Chl_a concentration.

At B1 station, the spatial relationship between Chl_a with $a_{\mathrm{ph}}$ (443), $a_{\mathrm{ph}}$ (670), $a^{*}{ }_{\mathrm{ph}}(443)$ and $a^{*}{ }_{\mathrm{ph}}(670)$ indicates a significant relationship between $a_{\mathrm{ph}}(670)$ and Chl_ $a\left(\mathrm{R}^{2}=0.69\right)$, whereas a weak relationship was found between the $a_{\mathrm{ph}}$ (443) and Chl_a with an $\mathrm{R}^{2}$ value of $0.15 . a_{\mathrm{ph}}$ (443) and $a_{\mathrm{ph}}^{*}$ (443) was highly variable at B1 station with an average value of $0.085 \pm 0.049 \mathrm{~m}^{-1}$ and $0.032 \pm 0.027 \mathrm{~m}^{2} \mathrm{mg}^{-1}$. At B2 station $a_{\mathrm{ph}}$ (443) and (670) showed a significant relationship with Chl_ $a$ with an $\mathrm{R}^{2}$ value of 0.63 and 0.77 respectively. The values of $a_{\mathrm{ph}}(670), a_{\mathrm{ph}}^{*}(670)$ and Chl_ $a$ were highly variable at B2 station the average being $0.029 \pm 0.028 \mathrm{~m}^{-1}, 0.013 \pm 0.009 \mathrm{~m}^{2} \mathrm{mg}^{-1}$, $2.95 \pm 3.46 \mathrm{mg} \mathrm{m}^{-3}$ respectively. At B3 station $a_{\mathrm{ph}}$ (443) and (670) showed a significant relationship with Chl_ $a$ with an $\mathrm{R}^{2}$ value of 0.90 and 0.96 respectively. Even though, a reasonable relationship was observed between $a^{*}$ ph (443) versus Chl_ $a$ with an $\mathrm{R}^{2}$ value of 0.56 . At B4 station $a_{\mathrm{ph}}$ (443) and (670) showed a significant relationship with Chl_ $a$ with an $\mathrm{R}^{2}$ value of 0.83 and 0.87 respectively. At all the four different bathymetry stations, $a^{*}{ }_{\mathrm{ph}}$ (443) and $a^{*}{ }_{\mathrm{ph}}$ (670) showed a weak relationship with Chl_a. During the entire period of the study, we observed that $a_{\mathrm{ph}}(670)$ was strongly correlated with Chl_ $a$ than $a_{\mathrm{ph}}$ (443). This could be attributed to the accessory pigment absorption, which is dominating more than Chl_ $a$ in the blue part of the spectrum (Shaju et al., 2015).

Based on the spectral shape and the ratio of phytoplankton specific absorption ( $\left.a^{*} \mathrm{ph}\right)$ value at $a_{\mathrm{ph}}^{*}(443) / a_{\mathrm{ph}}^{*}(670)$ seven different absorption spectra were identified as shown in Fig. 7. Shape_1 spectra showed two individual absorption peaks near 443 and $670 \mathrm{~nm}$ respectively, with the ratio of $a^{*}{ }_{\mathrm{ph}}(443) / a_{\mathrm{ph}}^{*}$ (670) being 1.99 . Shape- 1 spectra were highly dominated by Skeletonema sp. (5680 cells/L), Chaetoceros spp. (3500 cells/L). Average Chl_ $a$ concentration for the shape_1 spectra was $1.66 \mathrm{mg} \mathrm{m}^{-3}$. Shape_2 spectra showed peaks at 443 and $675 \mathrm{~nm}$ respectively, with an average ratio of $a^{*}{ }_{\mathrm{ph}}(443) / a_{\mathrm{ph}}^{*}(670)$ being 1.78. Shape_2 spectra were highly dominated by Skeletonema sp. $(10360$ cells/L). Average Chl_a concentration for the shape_2 spectra was $6.11 \mathrm{mg} \mathrm{m}^{-3}$. Shape_3 spectra also showed peaks at 443 and $677 \mathrm{~nm}$ respectively, with the value of $a^{*}{ }_{\mathrm{ph}}(443) / a_{\mathrm{ph}}^{*}$ (677) being 2.46. Shape_ 3 spectra were dominated by Chaetoceros sp. (4521 cells/ $\mathrm{L}$ ) and all the stations in shape_ 3 spectra were belonged to October. Average Chl_ $a$ concentration for the shape_3 spectra was $1.73 \mathrm{mg} \mathrm{m}^{-3}$. Shape_4 spectra showed peaks at 443 and $670 \mathrm{~nm}$ respectively, with an average ratio of 2.88 in $a^{*}{ }_{\mathrm{ph}}(443) / a^{*}{ }_{\mathrm{ph}}(670)$. Shape_4 spectra were dominated by Chaetoceros sp. (3309 cells/L) and all the stations in shape_4 spectra belonged to November. Average Chl_ $a$ concentration for the shape_4 spectra was $0.42 \mathrm{mg} \mathrm{m}^{-3}$. Shape_5 also showed peaks at 443 and $670 \mathrm{~nm}$ respectively, with an average ratio of 2.07 in $a^{*}{ }_{\mathrm{ph}}(443) / a_{\mathrm{ph}}^{*}(670)$. Shape_5 spectra were dominated by Chaetoceros sp. (3309 cells/L) and all the stations in shape_5 spectra belonged to November. Average Chl_ $a$ concentration for the shape_5 spectra was $0.42 \mathrm{mg} \mathrm{m}^{-3}$. Shape_6 showed identical peaks at 443 and $677 \mathrm{~nm}$ respectively, with an average ratio of 2.32 in $a^{*}$ ph (443)/ $a^{*}$ ph (670). Shape_6 was dominated by Skeletonema costatum (2533 cells/L) and Chaetoceros sp. (1168 cells/L). Average Chl_a concentration for the shape_6 spectra was $4.31 \mathrm{mg} \mathrm{m}^{-3}$. Shape_7 also showed peaks at 443 and $678 \mathrm{~nm}$ respectively, with an average ratio of 2.62 in $a^{*}$ ph (443) $/ a_{\text {ph }}^{*}$ (670). Shape_7 spectra were dominated by Coscinodiscus sp. The average value of Chl $a$ concentration for the shape_7 spectra was $1.44 \mathrm{mg} \mathrm{m}^{-3}$.

\subsection{Seasonal variability in diffuse attenuation coefficient}

The value of $K_{\mathrm{d}}$ (443) was higher during SWM ranged from 0.244 to $1.99 \mathrm{~m}^{-1}$ with an average value of $0.799 \pm 0.593 \mathrm{~m}^{-1}$ and showed a lower value during SIM ranged from 0.035 to $1.59 \mathrm{~m}^{-1}$ with an average value of $0.571 \pm 0.606 \mathrm{~m}^{-1}$. Similarly, $a_{\mathrm{d}}$ (443) showed a higher value during FIM ranged from 0.051 to $1.453 \mathrm{~m}^{-1}$ with an average value of $0.752 \pm 0.991 \mathrm{~m}^{-1}$ and shows a lower value during SIM ranged between $0.011-0.037 \mathrm{~m}^{-1}$ with an average value of

Table 4

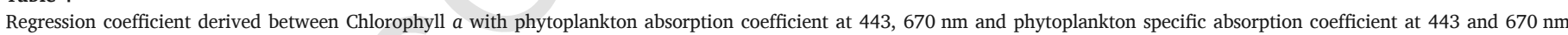
during Spring Inter Monsoon, South West Monsoon, Fall Inter Monsoon and Winter Monsoon along the coastal waters off Cochin.

\begin{tabular}{|c|c|c|c|c|c|c|}
\hline Seasons & Parameters & $\mathrm{R}^{2}$ & $\mathrm{n}$ & Regression type & Slope & Intercept \\
\hline \multirow[t]{4}{*}{ SIM } & $a_{\mathrm{ph}}(443)$ vs Chl_ $a$ & 0.65 & 12 & Linear & 0.023 & 0.009 \\
\hline & $a_{\mathrm{ph}}(670)$ vs Chl_a & 0.78 & 12 & Power & 0.013 & 0.763 \\
\hline & $a_{\mathrm{ph}}^{*}(443)$ vs Chl_ $a$ & 0.35 & 12 & Power & 0.034 & -0.401 \\
\hline & $a_{\mathrm{ph}}^{*}(670)$ vs Chl_ $a$ & 0.25 & 12 & Power & 0.013 & -0.237 \\
\hline \multirow[t]{4}{*}{ SWM } & $a_{\mathrm{ph}}(443)$ vs Chl_a & 0.89 & 8 & Power & 0.029 & 0.673 \\
\hline & $a_{\mathrm{ph}}(670)$ vs Chl_ $a$ & 0.94 & 8 & Power & 0.012 & 0.827 \\
\hline & $a_{\mathrm{ph}}^{*}(443)$ vs Chl_ $a$ & 0.65 & 8 & Power & 0.028 & -0.329 \\
\hline & $a_{\mathrm{ph}}^{*}(670)$ vs Chl_ $a$ & 0.46 & 8 & Linear & -0.0002 & 0.011 \\
\hline \multirow[t]{4}{*}{ FIM } & $a_{\mathrm{ph}}(443)$ vs Chl_a & 0.03 & 8 & Linear & 0.011 & 0.027 \\
\hline & $a_{\mathrm{ph}}(670)$ vs Chl_a & 0.02 & 8 & Power & 0.009 & -0.094 \\
\hline & $a_{\mathrm{ph}}^{*}(443)$ vs Chl_ $a$ & 0.44 & 8 & Power & 0.026 & -1.02 \\
\hline & $a_{\mathrm{ph}}^{*}(670)$ vs Chl_ $a$ & 0.68 & 8 & Power & 0.009 & -1.09 \\
\hline \multirow[t]{4}{*}{ WM } & $a_{\mathrm{ph}}(443)$ vs Chl_a & 0.52 & 10 & Power & 0.036 & 0.711 \\
\hline & $a_{\mathrm{ph}}(670)$ vs Chl_ $a$ & 0.69 & 10 & Power & 0.014 & 0.915 \\
\hline & $a_{\mathrm{ph}}^{*}(443)$ vs Chl_ $a$ & 0.17 & 10 & Power & -0.006 & 0.045 \\
\hline & $a_{\mathrm{ph}}^{*}(670)$ vs Chl_ $a$ & 0.05 & 10 & Linear & -0.002 & 0.017 \\
\hline
\end{tabular}




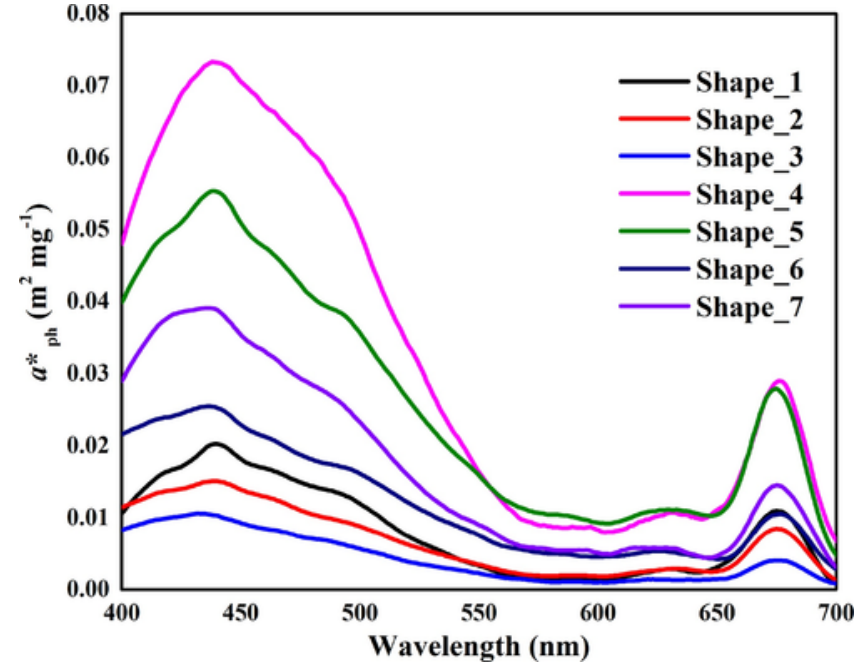

Fig. 7. Types of phytoplankton absorption spectra measured during the study period along the coastal waters off Cochin.

$0.028 \pm 0.015 \mathrm{~m}^{-1}$. The relationship between $K_{\mathrm{d}}$ (443), $a_{\mathrm{d}}(443)$ and Chl $a$ for SIM, SWM, FIM, and WM are shown (Fig. 8). During the study period, it was observed that $K_{\mathrm{d}}(443)$ and $a_{\mathrm{d}}$ (443) showed a decreasing trend from Barmouth station to the offshore stations. The regression coefficient derived between $K_{\mathrm{d}}$ (443), $a_{\mathrm{d}}$ (443) and Chl_ $a$ for SIM, SWM, FIM and WM are highlighted in (Table 5). During SIM a significant relationship existed between $K_{\mathrm{d}}(443)$ and $a_{\mathrm{d}}(443)$ as well as $K_{\mathrm{d}}(443)$ and Chl_ $a$ with an $\mathrm{R}^{2}$ value of 0.96 and 0.91 respectively (Table 5). The good correlation between $K_{\mathrm{d}}(443)$ and Chl_a proves that Chl_a significantly contributes to the light attenuation of the water column during SIM. During SWM, no significant relationship existed among any of the variables. However, a moderate relationship was observed between $K_{\mathrm{d}}$ (443) vs Chl_ $a$ with an $\mathrm{R}^{2}$ value of 0.59 showing Chl_ $a$ considerably contributing to light attenuation during FIM. During WM a positive correlation existed between $K_{\mathrm{d}}$ (443) and $a_{\mathrm{d}}$ (443) with an $\mathrm{R}^{2}$ value of 0.93 . During the study period, it was observed that detritus contributes significantly to light attenuation of the water column during SIM and WM. However, no significant relationship was found between TSM vs $K_{\mathrm{d}}$ (443) for SIM, SWM, FIM and WM seasons. The relationship between total suspended matter and downwelling diffuse attenuation coefficient is complex (Reynolds et al., 2016; Neukermans et al., 2012; Devlin et al., 2008).

\subsection{Absorption budget}

Fig. 9 showing the triangular classification of coastal waters based on the three optical components CDOM, phytoplankton and detritus at three different wavebands (443, 555, and $670 \mathrm{~nm}$ ). During the study period, highest contribution to the absorption budget was from detritus at $555 \mathrm{~nm}$; this has also reported by (Blondeau-patissier et al., 2017; Spyrakos et al., 2017). Similarly, detritus absorption showed a slightly decreasing trend at $670 \mathrm{~nm}$ while compared to 443 and $555 \mathrm{~nm}$. The results showed that optical characterization using triangular diagram provides a useful approach to identify the relative absorption contribu-
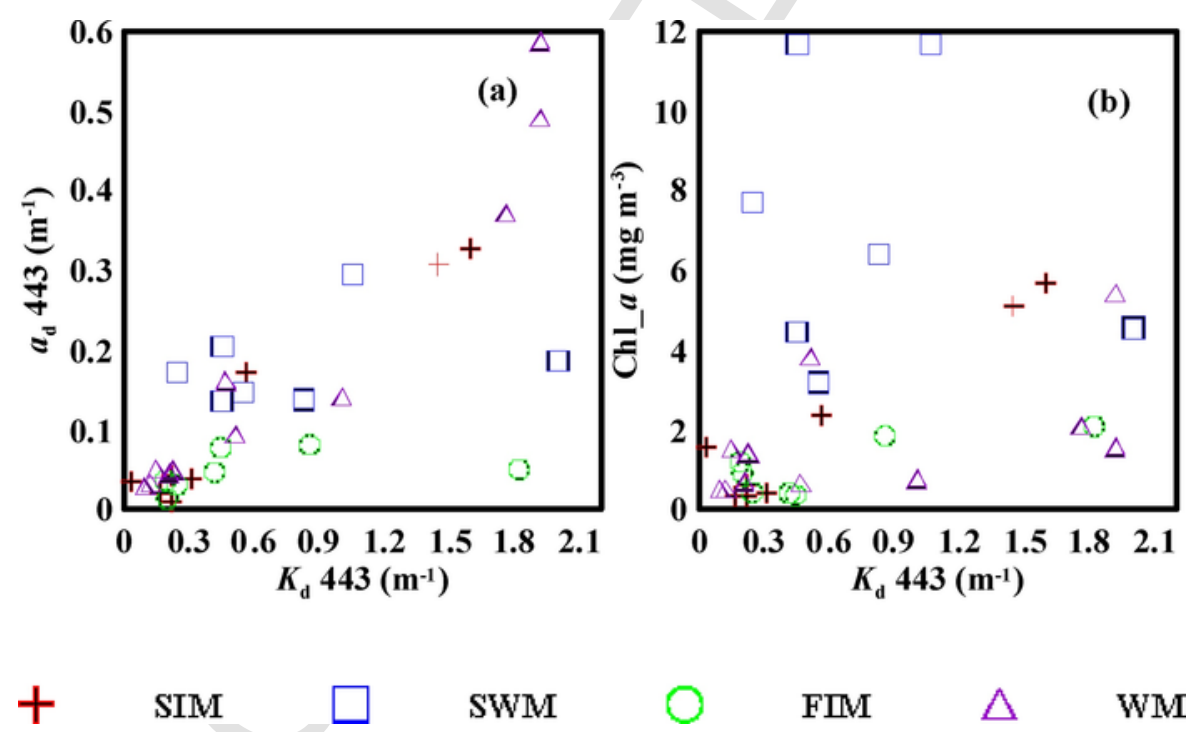

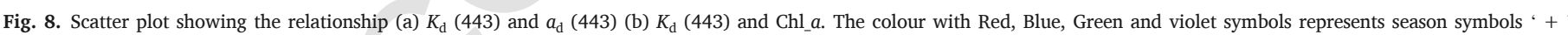

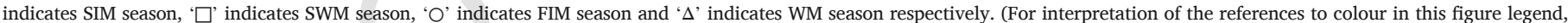
the reader is referred to the web version of this article.)

Table 5

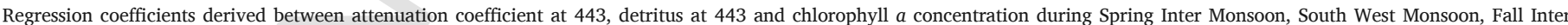
Monsoon and Winter Monsoon along the coastal waters off Cochin.

\begin{tabular}{|c|c|c|c|c|c|c|}
\hline Seasons & Parameters & $\mathrm{R}^{2}$ & $\mathrm{n}$ & Regression type & Slope & Intercept \\
\hline \multirow[t]{2}{*}{ SIM } & $K_{\mathrm{d}}(443)$ vs $a_{\mathrm{d}}(443)$ & 0.96 & 8 & Linear & 0.212 & -0.002 \\
\hline & $K_{\mathrm{d}}(443)$ vs Chl $a$ & 0.91 & 8 & Linear & 3.45 & 0.092 \\
\hline \multirow[t]{2}{*}{ SWM } & $K_{\mathrm{d}}(443)$ vs $a_{\mathrm{d}}(443)$ & 0.09 & 7 & Power & 0.187 & 0.125 \\
\hline & $K_{\mathrm{d}}(443)$ vs Chl_ $a$ & 0.03 & 7 & Linear & -0.896 & 7.81 \\
\hline \multirow[t]{2}{*}{ FIM } & $K_{\mathrm{d}}(443)$ vs $a_{\mathrm{d}}(443)$ & 0.39 & 7 & Power & 0.063 & 0.445 \\
\hline & $K_{\mathrm{d}}(443)$ vs Chl $a$ & 0.59 & 7 & Linear & 0.928 & 0.494 \\
\hline \multirow[t]{2}{*}{ WM } & $K_{\mathrm{d}}(443)$ vs $a_{\mathrm{d}}(443)$ & 0.93 & 11 & Linear & 0.257 & -0.009 \\
\hline & $K_{\mathrm{d}}(443)$ vs Chl $a$ & 0.37 & 11 & Power & 1.82 & 0.414 \\
\hline
\end{tabular}



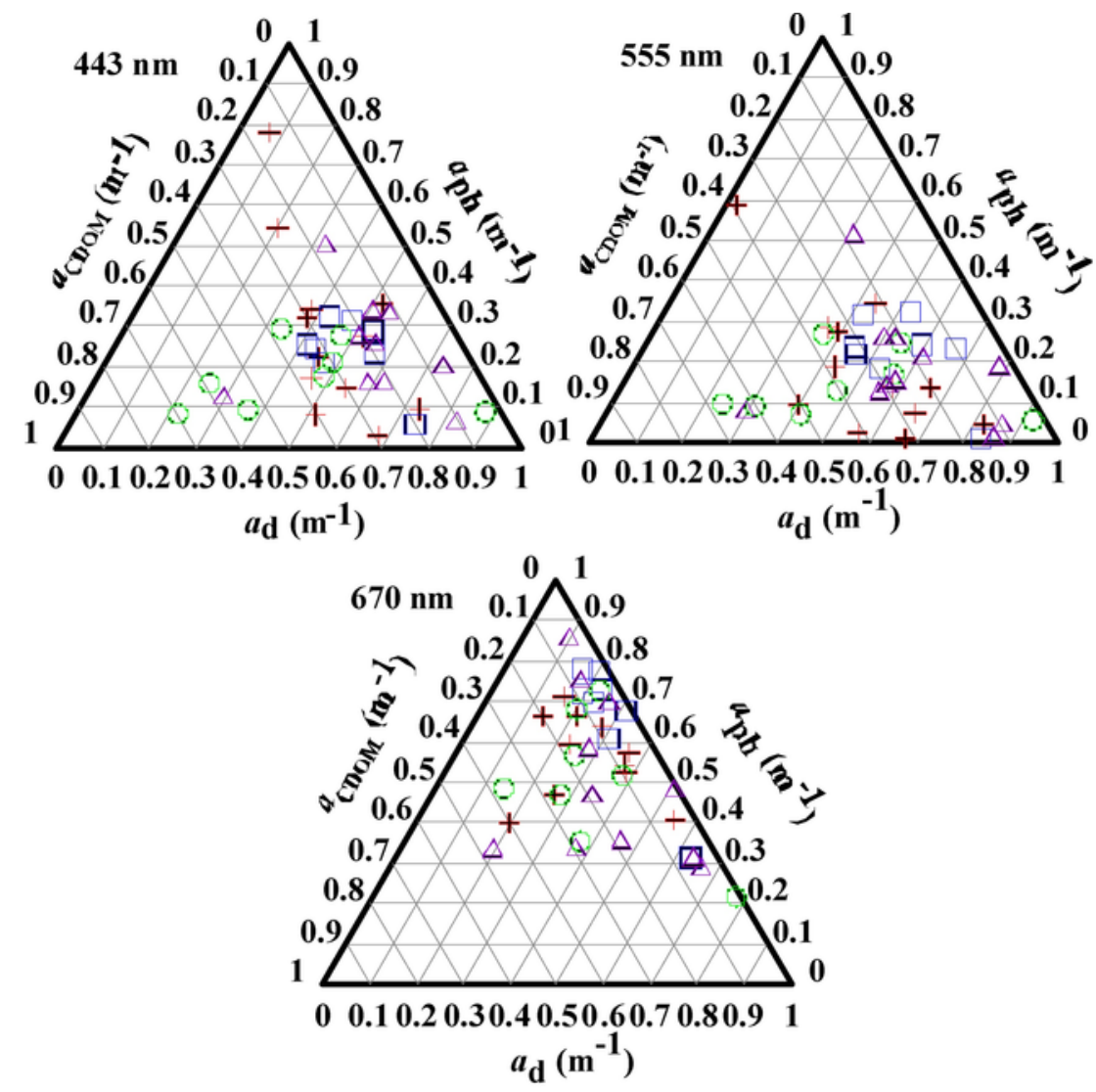

$+\quad$ SIM $\quad \square \quad$ SWM

FIM

$\triangle \quad$ WM

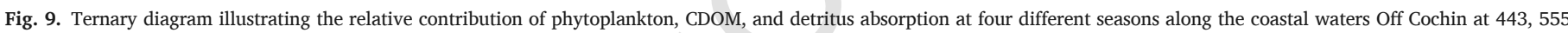

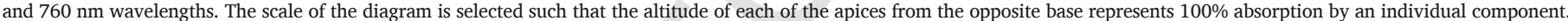

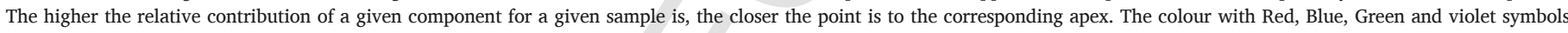

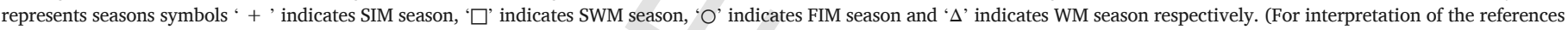
to colour in this figure legend, the reader is referred to the web version of this article.)

tion by CDOM, phytoplankton, and detritus materials in the water column. As per the triangular diagrammatic representation of Case 1 and Case 2 waters (Tilstone et al., 2012; Riddick et al., 2015; Mascarenhas et al., 2017), our results indicate typical Case 2 water bio-optics. The absorption budget at $443 \mathrm{~nm}$ was highly variable with a relative contribution of detritus at B1 station ranged between $20-90 \%$, B2 station ranged between 35-75\%, B3 station between 20-60\% and B4 station between $5-55 \%$. At Barmouth station, the relative contribution by detritus is more than $50 \%$ in most of the time. Similarly, the relative contribution of the detritus absorption was decreasing from Barmouth station to the offshore stations. Higher turbidity in Barmouth waters is due to the coastal runoff, coastal upwelling, vertical mixing, dredging, dumping of dredged materials and transportation activities and results in the alteration of water-column optical components (George et al., 2013). The relative absorption of phytoplankton at B1 station ranged from 5 to $30 \%$, B2 station between $10-35 \%$, B3 station between $15-55 \%$ and B4 station between $15-50 \%$. The relative absorption of $\mathrm{CDOM}$ at $\mathrm{B} 1$ station ranged between 5 to $70 \%$, B2 station between $15-55 \%$, B3 station between $15-60 \%$ and B4 station between 10-60\%. At $443 \mathrm{~nm}$, the relative absorption by detritus dominating more than the relative absorption of CDOM and phytoplankton, compose the coastal waters optically complex similar to coastal systems around Europe, North Sea and Eastern English Channel (Wozniak et al., 2011; Riddick et al., 2015; Tilstone et al., 2012). The relative contribution of phyto- plankton absorption was higher during SIM ranging from 5 to $80 \%$, and it is lesser than $50 \%$ in all other seasons. Higher relative CDOM absorption was showed during FIM with a relative contribution reaching $70 \%$. During WM the relative contribution of detritus absorption reaches up to $85 \%$. The relatively low contribution by phytoplankton during WM could be due to pigment packaging effect as well as the change in phytoplankton species composition (Matsuoka et al., 2011; Riddick et al., 2015).

The absorption budget at $555 \mathrm{~nm}$ was highly variable. The relative absorption of phytoplankton was higher during SIM ranging from 0 to $60 \%$, and it is lesser than $50 \%$ in all other seasons, except WM. The relative CDOM absorption was found higher during FIM reaching up to $65 \%$. During SIM the relative contribution of detritus absorption was reached up to $80 \%$.

The absorption budget at $670 \mathrm{~nm}$ indicates the relative absorption of detritus was found higher at FIM and reached up to $60 \%$. The absorption budget at $670 \mathrm{~nm}$ shows that relative absorption by detritus was more significant than the relative absorption by phytoplankton. However, relative absorption of $\mathrm{CDOM}$ was found to be decreased at $670 \mathrm{~nm}$ compared to 443 and $555 \mathrm{~nm}$. Similarly, relative absorption of detritus also found to be decreased at $670 \mathrm{~nm}$ compared to 443 and $555 \mathrm{~nm}$. The relative absorption of detritus dominated the relative absorption of phytoplankton and CDOM at 443, 555 and $670 \mathrm{~nm}$ wavelengths. 


\section{Conclusion}

The present study provides the seasonal and spatial variability in bio-optical properties along the coastal waters off Cochin, in South Eastern Arabian Sea (SEAS) for the first time and observed high variability in absorption components. $S_{\mathrm{CDOM}}$ decreased from Barmouth (B1) to offshore. The relative increase of $S_{\mathrm{CDOM}}$ in B1 station could be due to the freshwater discharge from the Cochin estuary. The observed insignificant relationship between Chl_ $a$ and TSM as well as TSM and $a_{\mathrm{CDOM}}$ (443) could be due to the enormous contribution of inorganic particles in total suspended matter discharged from Cochin estuary and the nonlinearity between Chl_ $a$ and ration of $a_{\mathrm{ph}}(443) / a_{\mathrm{ph}}(670)$, attributed to the intercellular composition of phytoplankton pigment and packaging effect. The dominance of the accessory pigment over Chl_ $a$ in the blue part of the spectrum resulted in the high correlation between phytoplankton absorption $\left(a_{\mathrm{ph}}\right)$ at $670 \mathrm{~nm}$ and Chl_ $a$ than $a_{\mathrm{ph}} 443$. Chl_ $a$ significantly contributes to the light attenuation of the water column during SIM, whereas detritus is an essential contributor to the light attenuation during SIM and WM. A detailed investigation is required on the size, shape, and composition of total suspended matter for understanding the role of suspended matter on light attenuation along the coastal waters off Cochin. The factors controlling the spatial distribution of CDOM during SIM was determined by both freshwater discharge and in-situ decomposition of phytoplankton biomass, and during SWM, it was by the terrestrial flesh out and from the upwelled water. The relative absorption of CDOM was high during FIM, and it is significantly correlated with Chl_a concentration. During WM, the high $\mathrm{S}_{\mathrm{CDOM}}$ with lower $a_{\mathrm{CDOM}}$ (443) values indicate that photo-degradation might affect the absorption characteristics of CDOM. The absorption budget describes the relative contribution of detritus, which is strongly dominated at all the three wavelengths. Results obtained in this study would help to improve our current understanding of optical absorption components and its computed spectral slope for improving and tuning the bio-optical algorithms for ocean colour remote sensing applications and biogeochemical processes in the Coastal Waters off Cochin.

\section{Uncited reference}

\section{Acknowledgements}

This study was funded by Space Application Centre (SAC), Indian Space Research Organization (ISRO), Ahmedabad. Second author thanks Partnership for Observation of Global Oceans (POGO) Secretariat, PML, UK for the fellowship during the study period. We thank the Department of Marine Biology, Microbiology and Biochemistry, Cochin University of Science and Technology (CUSAT) and Director, Nansen Environmental Research Centre (NERCI), India for the facilities provided. We are grateful to the staff of trawler Santa Cruz for the free help during the sampling period. We are thankful to Dominic Ricky Fernandez for the valuable assistance in plotting Fig. 1 . We are grateful to the anonymous reviewers for their valuable comments, which helped to improve the structure and content of this paper.

\section{References}

Bélanger, S., Cizmeli, S.A., Ehn, J., Matsuoka, A., Doxaran, D., Hooker, S., Babin, M., 2013. Light absorption and partitioning in Arctic Ocean surface waters: impact of multiyear ice melting. Biogeosciences 10, 6433-6452. https://doi.org/10.5194/ bg-10-6433-2013.

Barnes, M.K., Tilstone, G.H., Smyth, T.J., Suggett, D.J., Astoreca, R., Lancelot, C., Kromkamp, J.C., 2014. Absorption-based algorithm of primary production for total and size-fractionated phytoplankton in coastal waters. Mar. Ecol. Prog. Ser. 504, 73-89. https://doi.org/10.3354/meps10751.

Bauer, J.E., Cai, W.J., Raymond, P.A., Bianchi, T.S., Hopkinson, C.S., Regnier, P.A.G., 2013. The changing carbon cycle of the coastal ocean. Nature 504, 61-70. https://doi. org/10.1038/nature12857.

Blondeau-patissier, D., Gower, J.F.R., Dekker, A.G., Phinn, S.R., Brando, V.E., 2014. A review of ocean color remote sensing methods and statistical techniques for the detec- tion, mapping and analysis of phytoplankton blooms in coastal and open oceans. Prog. Oceanogr. 123, 123-144. https://doi.org/10.1016/j.pocean.2013.12.008.

Blondeau-patissier, D., Schroeder, T., Clementson, L.A., Brado, V.E., Purcell, D., Ford, P., Williams, D.K., Doxaran, D., Anstee, J., Thapar, N., Tovar-valencia, M., 2017. Bio-optical properties of two neigboring coastal regions of tropical northern Australia: the van diemen gulf and darwin harbour. Front. Mar. Sci. 4, 1-27. https://doi.org/10.3389/ fmars.2017.00114.

Brewin, R.J.W., Dall'Olmo, G., Sathyendranath, S., Hardman-Mountford, N.J., 2012. Particle backscattering as a function of chlorophyll and phytoplankton size structure in the open-ocean. Opt. Express. 20, 17632-17652. https://doi.org/10.1364/OE.20.017632.

Brezonik, P.L., Olmanson, L.G., Finlay, J.C., Bauer, M.E., 2015. Factors affecting the measurement of CDOM by remote sensing of optically complex inland waters. Remote Sens. Environ. 157, 199-215. https://doi.org/10.1016/j.rse.2014.04.033.

Campanelli, A., Pascucci, S., Betti, M., Grilli, F., Marini, M., Pignatti, S., Guicciardi, S., 2017. An empirical ocean colour algorithm for estimating the contribution of coloured dissolved organic matter in north-central western adriatic sea. Remote Sens. 9 (2)https://doi.org/10.3390/rs9020180.

Carder, K.L., Steward, R.G., Harvey, G.R., Ortner, P.B., 1989. Marine humic and fulvic acids: their effects on remote sensing of ocean chlorophyll. Limnol. Oceanogr. 34 , 68-81.

Cleveland, J.S., Weidemann, A.D., 1993. Quantifying absorption by aquatic particles: a multiple scattering correction for glass-fiber filters. Limnol. Oceanogr. 38, 1321-1327. https://doi.org/10.4319/lo.1993.38.6.1321.

Davidson, K., Gowen, R.J., Harrison, P.J., Fleming, L.E., Hoagland, P., Moschonas, G., 2014. Anthropogenic nutrients and harmful algae in coastal waters. J. Environ. Manage 146, 206-216. https://doi.org/10.1016/j.jenvman.2014.07.002.

Devlin, M.J., Barry, J., Mills, D.K., Gowen, R.J., Foden, J., Sivyer, D., Tett, P., 2008. Relationships between suspended particulate material, light attenuation and Secchi depth in UK marine waters. Estuar. Coast. Shelf Sci. 79, 429-439. https://doi.org/10.1016/ j.ecss.2008.04.024.

Devred, E., Turpie, K.R., Moses, W., Klemas, V.V., Moisan, T., Babin, M., Toro-Farmer, G., Forget, M.H., Jo, Y.H., 2013. Future retrievals of water column bio-optical properties using the hyperspectral infrared imager (hyspiri). Remote Sens. 5, 6812-6837. https: //doi.org/10.3390/rs5126812.

Dogliotti, A.I., Ruddick, K.G., Nechad, B., Doxaran, D., Knaeps, E., 2015. A single algorithm to retrieve turbidity from remotely-sensed data in all coastal and estuarine waters. Remote Sens. Environ. 156, 157-168. https://doi.org/10.1016/j.rse.2014.09. 020 .

Fargion, G.S., Mueller, J.L., 2000. NASA/TM-2000-209966 Ocean Optics Protocols For Satellite Ocean Color Sensor Validation, Revision 2. Goddard Sp. Flight Sp. Center, Greenbelt, Maryl, 1-184.

Ferrari, G.M., Dowell, M.D., Grossi, S., Targa, C., 1996. Relationship between the optical properties of chromophoric dissolved organic matter and total concentration of dissolved organic carbon in the southern Baltic Sea region. Mar. Chem. 55, 299-316.

Ferreira, A., Ciotti, Á.M., Coló Giannini, M.F., 2014. Variability in the light absorption coefficients of phytoplankton, non-algal particles, and colored dissolved organic matter in a subtropical bay (Brazil). Estuar. Coast. Shelf Sci. 139, 127-136. https://doi.org/ 10.1016/j.ecss.2014.01.002.

Garaba, S.P., Voß, D., Zielinski, O., 2014. Physical, bio-Optical state and correlations in North-Western European shelf seas. Remote Sens. 6, 5042-5066. https://doi.org/10. $3390 / \mathrm{rs} 6065042$

George, R., Muraleedharan, K.R., Martin, G.D., Sabu, P., Gerson, V.J., Dineshkumar, P.K., Nair, S.M., Chandramohanakumar, N., Nair, K.K.C., 2013. Nutrient biogeochemistry of the eastern Arabian Sea during the southwest monsoon retreat. Environ. Earth Sci. 68, 703-718. https://doi.org/10.1007/s12665-012-1772-2.

Gokul, E.A., Shanmugam, P., Sundarabalan, B., Sahay, A., Chauhan, P., 2014. Modelling the inherent optical properties and estimating the constituents' concentrations in turbid and eutrophic waters. Cont. Shelf Res. 84, 120-138. https://doi.org/10.1016/j. csr.2014.05.013.

Grasshoff, K., Krembling, K., Ehrhardt, M., 1983. Methods of Seawater Analysis. Wiley Verlag Chemie, Germany.

Green, S.A., Blough, N.V., 1994. Optical absorption and fluorescence properties of chromophoric dissolved organic matter in natural waters. Limonol. Oceanogr. 39, 1903-1916. https://doi.org/10.4319/lo.1994.39.8.1903.

Greg Mitchell, B., Holm-Hansen, O., 1991. Bio-optical properties of Antarctic Peninsula waters: differentiation from temperate ocean models. Deep Sea Res. Part A. Oceanogr. Res. Pap. https://doi.org/10.1016/0198-0149(91)90094-V.

Gupta, G.V.M., Sudheesh, V., Sudharma, K.V., Saravanane, N., Dhanya, V., Dhanya, K.R., Lakshmi, G., Sudhakar, M., Naqvi, S.W.A., 2016. Evolution to decay of upwelling and associated biogeochemistry over the southeastern Arabian Sea shelf. J. Geophys. Res. 121, 159-175. https://doi.org/10.1002/2015JG003163.

Han, B., Loisel, H., Vantrepotte, V., Mériaux, X., Bryère, P., Ouillon, S., Dessailly, D., Xing, Q., Zhu, J., 2016. Development of a semi-analytical algorithm for the retrieval of suspended particulate matter from remote sensing over clear to very turbid waters. Remote Sens. 8. https://doi.org/10.3390/rs8030211.

Hansen, A.M., Kraus, T.E.C., Pellerin, B.A., Fleck, J.A., Downing, B.D., Bergamaschi, B.A., 2016. Optical properties of dissolved organic matter (DOM): Effects of biological and photolytic degradation. Limnol. Oceanogr. 61, 1015-1032. https://doi.org/10.1002/ lno.10270.

Kishino, M., Takahashi, M., Okami, N., Ichimura, S., 1985. Estimation of the spectral absorption coefficients of phytoplankton in a thermally stratified sea. Bull. Mar. Sci. 37, 634-642.

Knaeps, E., Ruddick, K.G., Doxaran, D., Dogliotti, A.I., Nechad, B., Raymaekers, D., Sterckx, S., 2015. A SWIR based algorithm to retrieve total suspended matter in ex- 
tremely turbid waters. Remote Sens. Environ. 168, 66-79. https://doi.org/10.1016/j.rse. 2015.06.022.

Kowalczuk, P., Kaczmarek, S., 1996. Analysis of temporal and spatial variability of Yellow Substance absorption in the Southern Baltic. Oceanologia 1, 3-32.

Kyewalyanga, M.N., Platt, T., Sathyendranath, S., Lutz, V.A., Stuart, V., 1998. Seasonal variations in physiological parameters of phytoplankton across the North Atlantic. J. Plankton Res. 20, 17-42.

Loisel, H., Vantrepotte, V., Jamet, C., Dat, D.N., 2013. Challenges and new advances in ocean color remote sensing of coastal waters. Oceanogr. Res 1-38. https://doi.org/10. $5772 / 56414$.

Mélin, F., Vantrepotte, V., 2015. How optically diverse is the coastal ocean? Remote Sens. Environ160, 235-251. https://doi.org/10.1016/j.rse.2015.01.023.

Mannino, A., Novak, M.G., Hooker, S.B., Hyde, K., Aurin, D.m., 2014. Algorithm development and validation of CDOM properties for estuarine and continental shelf waters along the northeastern. Remote Sens. Environ 152. https://doi.org/10.1016/j.rse. 2014.06.027.

Mascarenhas, V.J., Vob, D., Wollschlaeger, J., Zielinski, O., 2017. Fjord light regime: bio-optical variability, absorption budget, and hyperspectral light availability in Sognefjord and Trondheimsfjord, Norway. J. Geophys. Res. Oceans 122, 1-17. https: //doi.org/10.1002/2016JC012332.

Matsuoka, A., Hill, V., Huot, Y., Babin, M., Bricaud, A., 2011. Seasonal variability in the light absorption properties of western Arctic waters: parameterization of the individual components of absorption for ocean color applications. J. Geophys. Res. 116, 1-15. https://doi.org/10.1029/2009JC005594.

Matsuoka, A., Ortega-retuerta, E., Bricaud, A., Arrigo, K.R., Babin, M., 2015. Characteristics of colored dissolved organic matter (CDOM) in the Western Arctic Ocean: relationships with microbial activities. Deep. Res. Part II 118, 44-52. https://doi.org/10. 1016/j.dsr2.2015.02.012.

Menon, H.B., Lotliker, A.A., Moorthy, K.K., Nayak, S.R., 2006. Variability of remote sensing reflectance and implications for optical remote sensing - A study along the eastern and northeastern waters of Arabian Sea. Geophys. Res. Lett. 33, 2-6. https://doi. org/10.1029/2006GL026026.

Menon, H.B., Sangekar, N.P., Lotlikker, A.A., Vethamony, P., 2011. Dynamics of chromophoric dissolved organic matter in Mandovi and Zuari estuaries - A study through in situ and satellite data. ISPRS J. Photogramm. Remote Sens. 66 (4), 545-552.

Minu, P., Lotliker, A.A., Shaju, S.S., SanthoshKumar, B., Ashraf, P.M., Meenakumari, B., 2014. Effect of optically active substances and atmospheric correction schemes on remote-sensing reflectance at a coastal site off Kochi. Int. J. Remote Sens. 35, 5434-5447. https://doi.org/10.1080/01431161.2014.926420.

Minu, P., Lotliker, A.A., Shaju, S.S., Ashraf, P.M., Kumar, T.S., Meenakumari, B., 2016. Performance of operational satellite bio-optical algorithms in different water types in the southeastern Arabian Sea. Oceanologia58, 317-326.

Moore, T.S., Dowell, M.D., Bradt, S., Ruiz Verdu, A., 2014. An optical water type framework for selecting and blending retrievals from bio-optical algorithms in lakes and coastal waters. Remote Sens. Environ. 143, 97-111. https://doi.org/10.1016/j.rse. 2013.11.021.

Mouw, C.B., Greb, S., Aurin, D., DiGiacomo, P.M., Lee, Z., Twardowski, M., Binding, C., Hu, C., Ma, R., Moore, T., Moses, W., Craig, S.E., 2015. Aquatic color radiometry remote sensing of coastal and inland waters: challenges and recommendations for future satellite missions. Remote Sens. Environ. 160, 15-30. https://doi.org/10.1016/j.rse. 2015.02.001.

Nelson, N.B., Siegel, D.A., Carlson, C.A., Swan, C.M., 2010. Tracing global biogeochemical cycles and meridional overturning circulation using chromophoric dissolved organic matter. Geophys. Res. Lett. 37. https://doi.org/10.1029/2009GL042325.

Neukermans, G., Loisel, H., Meriaux, X., Astoreca, R., Mckee, D., 2012. In situ variability of mass specific beam attenuation and backscattering of marine particles with respect to particle size, density, and composition. Limnol. Oceanogr. 57, 124-144. https:// doi.org/10.4319/lo.2011.57.1.0124

Nima, C., Frette, , Hamre, B., Erga, S.R., Chen, Y., Zhao, L., Sørensen, K., Norli, M., Stamnes, K., Stamnes, J.J., 2016. Absorption properties of high-latitude Norwegian coastal water: the impact of CDOM and particulate matter. Estuar. Coast. Shelf Sci. 178, 158-167. https://doi.org/10.1016/j.ecss.2016.05.012.

Organelli, E., Bricaud, A., Antoine, D., Matsuoka, A., 2014. Seasonal dynamics of light absorption by chromophoric dissolved organic matter (CDOM) in the NW Mediterranean Sea (BOUSSOLE site). Deep. Res. Part I 91, 72-85. https://doi.org/10.1016/j. dsr.2014.05.003.

Pérez, G.L., Galí, M., Royer, S.J., Sarmento, H., Gasol, J.M., Marrasé, C., Simó, R., 2016 Bio-optical characterization of offshore NW Mediterranean waters: CDOM contribution to the absorption budget and diffuse attenuation of downwelling irradiance. Deep. Res. Part I 114, 111-127. https://doi.org/10.1016/j.dsr.2016.05.011.

Reynolds, R.A., Stramski, D., Neukermans, G., 2016. Optical backscattering by particles in Arctic seawater and relationships to particle mass concentration, size distribution, and bulk composition. Limnol. Oceanogr. 61 (5), 1869-1890. https://doi.org/10.1002/ lno.10341.

Riddick, C.A.L., Hunter, P.D., Tyler, A.N., Vicente, V.M., Horvath, H., Kovas, A.W., Voros, L., Presto, T., Presing, M., 2015. Spatial Variability of absorption coefficient over a biogeochemical gradient in a large and optically complex shallow lake. J. Geophys. Res. 1-17. https://doi.org/10.1002/2014JC010320.

Shaju, S.S., Minu, P., Srikanth, A.S., Ashraf, P.M., Vijayan, A.K., Meenakumari, B., 2015. Decomposition study of in vivo phytoplankton absorption spectra to identify the pigments and phytoplankton group in complex case 2 waters of coastal Arabian Sea. Oceanol. Hydrobiol. Stud. 44 (3), 1-12.
Shanmugam, P., 2011. A new bio-optical algorithm for the remote sensing of algal blooms in complex ocean waters. J. Geophys. Res. 116, 1-12. https://doi.org/10. 1029/2010JC006796.

Shynu, R., Rao, V.P., Samiksha, S.V., Vethamony, P., Naqvi, S.W.A., Kessarkar, P.M., Babu, M.T., Dineshkumar, P.K., 2017. Suspended matter and fluid mud off Alleppey, southwest coast of India. Estuar. Coast. Shelf Sci. 185, 31-43. https://doi.org/10.1016/j. ecss.2016.11.023.

Siegel, D.A., Behrenfeld, M.J., Maritorena, S., McClain, C.R., Antoine, D., Bailey, S.W., Bontempi, P.S., Boss, E.S., Dierssen, H.M., Doney, S.C., Eplee, R.E., Evans, R.H., Feldman, G.C., Fields, E., Franz, B.A., Kuring, N.A., Mengelt, C., Nelson, N.B., Patt, F.S. Robinson, W.D., Sarmiento, J.L., Swan, C.M., Werdell, P.J., Westberry, T.K., Wild ing, J.G., Yoder, J.A., 2013. Regional to global assessments of phytoplankton dynamics from the SeaWiFS mission. Remote Sens. Environ. 135, 77-91. https://doi.org/10. 1016/j.rse.2013.03.025.

Spyrakos, E., Donnell, R.O., Hunter, P.D., Miller, C., Scott, M., Simis, S.G.H., Neil, C., Barbosa, C.C.F., Binding, C.E., Bradt, S., Bresciani, M., Olmo, G.D., Giardino, C., Gitelson, A.A., Kutser, T., Li, L., Matsushita, B., Martinez-vicente, V., Matthews, M.W. Ogashawara, I., Ruiz-Verdu, A., Schalles, J.F., Tebbs, E., Zhang, Y., Tyler, A.N., 2017. Optical types of inland and coastal waters. Limnol. Oceanogr. https://doi.org/10. 1002/lno.10674

Sravanthi, N., Ramana, I.V., Yunus Ali, P., Ashraf, M., Ali, M.M., Narayana, A.C., 2013. An algorithm for estimating suspended sediment concentrations in the coastal waters of india using remotely sensed reflectance and its application to coastal environments. Int. J. Environ. Res. 7, 841-850.

Stedmon, C.A., Markager, S., 2003. Behaviour of the optical properties of coloured dissolved organic matter under conservative mixing. Estuar. Coast. Shelf Sci. 57, 973-979. https://doi.org/10.1016/S0272-7714(03)00003-9.

Strickland, J.D.H., Parsons, T.R., 1972. A Practical Handbook of Seawater Analysis A Pract. Hand b. Sea Water Anal. 167, 185. https://doi.org/10.1002/iroh 19700550118.

Sudheesh, V., Gupta, G.V.M., Sudharma, K.V., Naik, H., Shenoy, D.M., Sudhakar, M. Naqvi, S.W.A., 2016. Factors Controlling Enhanced N2O Concentrations over the Southwestern Indian Shelf. https://doi.org/10.1002/2016JC012166.

Sudheesh, V., Movitha, M., Hatha, A.A.M., Renjith, K.R., Resmi, P., Rahiman, M., Nair S.M., 2017. Effects of seasonal anoxia on the distribution of phosphorus fractions in the surface sediments of southeastern Arabian Sea shelf. Cont. Shelf Res. 0-1. https:// doi.org/10.1016/j.csr.2017.09.011.

Sun, D., Hu, C., Qiu, Z., Cannizzaro, J.P., Brian, B.B., 2014. Influence of red band-based water classification approach on chlorophyll algorithms for optically complex estuaries. Remote Sens. Environ. https://doi.org/10.1016/j.rse.2014.08.035.

Tilstone, G.H., Peters, S.W.M., Van der Woerd, H.J., Eleveld, M.A., Ruddick, K., Schonfeld, W., Krasemann, H., Martinez-Vicente, V., Blondeau-patissier, D., Rottgers, R. Sorensen, K., Jorgensen, P.V., Shutler, J.D., 2012. Variability in specific-absorption properties and their 6use in a semi-analytical ocean colour algorithm for MERIS in North Sea and Western English Channel Coastal Waters. Remote Sens. Environ. 118, 320-338. https://doi.org/10.1016/j.rse.2011.11.019.

Tilstone, G.H., Lotliker, A.A., Miller, P.I., Ashraf, P.M., Kumar, T.S., Suresh, T., Ragavan, B.R., Menon, H.B., 2013. Assessment of MODIS-Aqua chlorophyll-a algorithms in coastal and shelf waters of the eastern Arabian Sea. Cont. Shelf Res. 65, 14-26. https: //doi.org/10.1016/j.csr.2013.06.003

Tiwari, S.P., Shanmugam, P., 2011. An optical model for the remote sensing of coloured dissolved organic matter in coastal/ocean waters. Estuar. Coast. Shelf Sci. 93, 396-402. https://doi.org/10.1016/j.ecss.2011.05.010.

Uitz, J., Stramski, D., Reynolds, R.A., Dubranna, J., 2015. Assessing phytoplankton community composition from hyperspectral measurements of phytoplankton absorption coefficient and remote-sensing reflectance in open-ocean environments. Remote Sens. Environ. 171, 58-74. https://doi.org/10.1016/j.rse.2015.09.027.

Varunan, T., Shanmugam, P., 2015. A model for estimating size-fractioned phytoplankton absorption coefficients in coastal and oceanic waters from satellite data. Remote Sens. Environ. 158, 235-254. https://doi.org/10.1016/j.rse.2014.11.008.

Welschmeyer, N.A., 1985. Fluorometric analysis of chlorophyll a in the presence of chlorophyll b and pheopigments. Limnol. Oceanogr. 39. https://doi.org/10.4319/lo.1994. 39.8.1985.

Wozniak, S.B., Meler, J., Lednicka, B., Zdun, A., Ston-Egiert, J., 2011. Inherent optical properties of suspended particulate matter in the southern Baltic Sea. Oceanologia 53, 691-729. https://doi.org/10.5697/oc.53-3.691.

Xing, X., Claustre, H., Wang, H., Poteau, A., D'Ortenzio, F., 2014. Seasonal dynamics in colored dissolved organic matter in the Mediterranean Sea: patterns and drivers. Deep. Res. Part I Oceanogr. Res. Pap. 83, 93-101. https://doi.org/10.1016/j.dsr.2013.09. 008

Zhai, L., Tang, C., Platt, T., Sathyendranath, S., 2011. Ocean response to attenuation of visible light by phytoplankton in the Gulf of St. Lawrence. J. Mar. Syst. 88, 285-297. https://doi.org/10.1016/j.jmarsys.2011.05.005.

Zhang, X., Stavn, R.H., Falster, A.U., Gray, D., Gould, R.W., 2014. New insight into particulate mineral and organic matter in coastal ocean waters through optical inversion. Estuar. Coast. Shelf Sci. 149, 1-12. https://doi.org/10.1016/j.ecss.2014.06.003.

Zhang, Y., Ma, R., Duan, H., Loiselle, S., Xu, J., 2014. A spectral decomposition algorithm for estimating chlorophyll-a concentrations in lake taihu, China. Remote Sens. 6, 5090-5106. https://doi.org/10.3390/rs6065090.

Zheng, G., Stramski, D., Reynolds, R.A., 2014. Evaluation of the Quasi-Analytical Algorithm for estimating the inherent optical properties of seawater from ocean color: comparison of Arctic and lower-latitude waters. Remote Sens. Environ. 155, 194-209. https://doi.org/10.1016/j.rse.2014.08.020. 